\title{
W obliczu kataklizmu. Zabezpieczenie zbiorów Muzeum Narodowego w Krakowie przed pierwszą i drugą wojną światową
}

\begin{abstract}
Abstrakt: Autorka koncentruje się na ochronie zabytków podczas I i II wojny światowej. Krakowskie Muzeum Narodowe jest niezwykle ciekawym przykładem, gdyż w obydwu przypadkach odpowiedzialność spoczywała na tej samej osobie - Feliksie Koperze. Za pierwszym razem jego decyzje były efektem pomysłowości, a później umiejętności wyciągania wniosków z własnych doświadczeń. W obydwu sytuacjach wynikały z niezwykłej determinacji i odpowiedzialności za powierzoną mu bezcenną kolekcję oraz wytycznych władz zwierzchnich.
\end{abstract}

Słow a klu c z ow e: I wojna światowa, II wojna światowa, ochrona zbiorów, Muzeum Narodowe w Krakowie, Feliks Kopera, Kraków, muzealnictwo.

Abstract: The author focuses on the protection of monuments during the First and the Second World War. The National Museum in Krakow is an extremely interesting example, because in both cases responsibility rests with the same person - Feliks Kopera. At first, his decisions were the result of ingenuity and, later the ability to draw conclusions from personal experience. In both cases, it was the result of extraordinary determination and responsibility for priceless collections entrusted to him and the guidance provided to him by the higher authorities.

Keywords: World War First, World War Second, protection of art collections, National Museum in Krakow, Feliks Kopera, Krakow, museology. 
„Wobec olbrzymich zniszczeń, jakich Polska doznała wskutek kataklizmów dziejowych i ostatnich wojen, ratowanie bezcennych dla historii i kultury Narodu zabytków oraz wszelkiego rodzaju mienia artystycznego i kulturalnego jest nakazem chwili”'.

Konflikty zbrojne XIX w., a szczególnie dwie wojny światowe w następnym stuleciu unaoczniły, że współczesne metody prowadzenia walk to jedno z największych zagrożeń dla światowego dziedzictwa. Straty wśród dóbr kultury, stanowiące wynik celowego niszczenia były tak ogromne, że wywołały konieczność prowadzenia działań mających na celu ich ochronę poprzez międzynarodowe układy i porozumienia. Pierwsze prace podjęto w 1874 na międzynarodowej konferencji w Brukseli, gdzie wypracowano deklarację praw i zwyczajów wojny lądowej. Dokument ten nie został ratyfikowany, ale stanowił podstawę obrad konferencji w Hadze w 1899 i 1907 oraz podpisanych tam konwencji, wśród nich IV i IX, które - chociaż w ograniczonym zakresie odnosiły się jednak do ochrony dóbr kultury i były pierwszą międzynarodowa kodyfikacją zatwierdzona przez większość cywilizowanych państw. Polska ratyfikowała konwencję IV w 1927 i IX w 1936 r.

Wobec dramatu, który rozegrał się podczas II wojny światowej, prace podjęto na nowo i uwieńczyło je podpisanie $14 \mathrm{~V} 1954$ konwencji haskiej o ochronie dóbr kulturalnych $\mathrm{w}$ razie konfliktu zbrojnego. W kolejnych latach powstał szereg dalszych dokumentów mających na celu zabezpieczenie dziedzictwa kulturowego ${ }^{2}$. Niestety zapisy te pozostaja tylko martwa litera - w konfliktach zbrojnych dobra kultury sa nadal niszczone, w wielu przypadkach z premedytacja. Działania takie miały miejsce m.in. podczas wojny w Korei w 1950-1953, Wietnamie w 1961-1975, wojen na Bliskim Wschodzie: wojny sześciodniowej w 1967, wojny Jom Kippur w 1973, wojny w Afganistanie w 2001, a także wojny w byłej Jugosławii w latach 1991-1995. Tragiczny akcent stanowią również barbarzyńskie akty celowego niszczenia

\footnotetext{
${ }^{1}$ Archiwum Akt Nowych (dalej: AAN), Ministerstwo Wyznań Religijnych i Oświecenia Publicznego (dalej: MWRiOP), sygn. 7054, pismo do Głównego Komisarza Cywilnego z września 1939, k. 329.

${ }^{2}$ Między innymi Konwencja dotycząca środków zmierzających do zakazu i zapobiegania nielegalnemu przywozowi, wywozowi i przenoszeniu własności dóbr kultury (Paryż, 17 XI 1970); Europejska konwencja o przestępstwach przeciwko dobrom kultury (Delfy, 23 VI 1985); Porozumienie o współpracy i pomocy wzajemnej w sprawie zatrzymania i zwrotu dóbr kultury nielegalnie przewożonych przez granice państw sporządzone (Płowdiw, 22 IV 1986); Dyrektywa Rady 93/7/EWG z 15 III 1993 w sprawie zwrotu dóbr kultury wyprowadzonych niezgodnie z prawem z terytorium państwa członkowskiego; Konwencja UNIDROIT o skradzionych lub nielegalnie wywiezionych dobrach kultury (24 VI 1995); Konwencja w sprawie ochrony archeologicznego, historycznego i artystycznego dziedzictwa narodów amerykańskich (San Salvador, 16 VI 1976), a także Kodeks etyki ICOM dla muzeów z 4 XI 1986 z późniejszymi zmianami oraz liczne dokumenty Zgromadzenia Ogólnego ONZ i Parlamentu Europejskiego.
} 
dziedzictwa kulturowego na Bliskim Wschodzie, którego dopuszczają się oddziały samozwańczego Państwa Islamskiego.

Wybuch zarówno I, jak i II wojny światowej, chociaż w pewnym stopniu przewidywany, a nawet oczekiwany, był zaskoczeniem. Niewyobrażalny okazał się rozmiar konfliktów, niespotykane było tempo prowadzonych działań wojennych i ich skala oraz bezwzględność dla eksterminacji ludzkiego istnienia również w aspekcie dziedzictwa kulturowego.

Niniejszy artykuł to studium porównawcze prezentujace stan zabezpieczenia zbiorów Muzeum Narodowego w Krakowie (dalej: Muzeum) w obliczu tych wydarzeń. Dwa globalne konflikty zbrojne rozegrały się w bliskiej, dwudziestopięcioletniej perspektywie. Instytucją zarządzała wciąż ta sama osoba - Feliks Kopera ${ }^{3}$, który borykał się w jednym i w drugim przypadku z podobnymi problemami - brakiem czasu, ludzi, pieniędzy i odpowiedniego wyposażenia. Działania prowadził intuicyjnie, podejmował decyzje samodzielnie, biorąc na swoje barki odpowiedzialność za ewentualne błędy. Doświadczenia I wojny światowej niezaprzeczalnie rzutowały na perspektywę, jaka przyjął wobec drugiego konfliktu, z jednej strony ukazujace, z jak wielkim zagrożeniem może przyjść się zmierzyć, z drugiej nie dopuszczając do świadomości możliwości powtórzenia działań na tak szeroką - światową skalę. Wielka Wojna z perspektywy końca lat trzydziestych XX w. była historia, której dramat wciąż pozostawał niewyobrażalny i nie powinien się powtórzyć.

\section{Zabezpieczenie zbiorów podczas I wojny światowej}

Akcję zabezpieczania zbiorów Muzeum na wypadek działań wojennych rozpoczęto w drugiej połowie 1914 r. Było to związane z błyskawicznym rozwojem sytuacji po zamordowaniu arcyksięcia Franciszka Ferdynanda w Sarajewie. 6 VIII 1914 Austria wypowiedziała wojnę Rosji i niedługo potem Kraków znalazł się w bezpośrednim zagrożeniu działaniami wojennymi. Niebezpieczeństwo minęło dopiero w grudniu 1914 wraz z odrzuceniem przez armię austriacką wojsk rosyjskich za linię Dunajca, a ostatecznie po bitwie pod Gorlicami w maju $1915^{4}$.

\footnotetext{
${ }^{3}$ Na temat F. Kopery zob. D. Błońska, Feliks Kopera (1871-1952). Menadżer kultury, naukowiec i dydaktyk. W 60. rocznice śmierci, „Rozprawy Muzeum Narodowego w Krakowie. Seria Nowa” 2012, t. V, s. 313-331 (tam bibliografia).

4 J.M. Małecki, W dobie autonomii galicyjskiej (1866-1918), w: Kraków w latach 1796-1918, seria: „Dzieje Krakowa”, t. III, red. J. Bieniarzówna, J.M. Małecki, Kraków 1979, s. 383-394. Na temat zabezpieczeń zbiorów Muzeum wzmianki również w: A. Kopff, Muzeum Narodowe $w$ Krakowie. Historia i zbiory, Kraków 1962, s. 34-35. Na temat losów zabytków w Europie podczas I wojny światowej zob. E. Manikowska, Wielka wojna i zabytki, w: Polskie dziedzictwo kulturowe u progu niepodlegtości wokót Towarzystwa Opieki nad Zabytkami Przeszłości, red. E. Manikowska, P. Jamski, Warszawa 2010, s. 21-92.
} 
Kopera od początku organizował akcję samodzielnie, wykorzystując będące w posiadaniu Muzeum środki finansowe i pracowników, gdyż wytyczne ze strony miasta - i to w ograniczonym zakresie - oraz pomoc finansowa przyszły dopiero w połowie października. Budynki, którymi dysponowało Muzeum, były jedynie przystosowane do celów muzealnych, nie posiadały zabezpieczeń typowych dla schronów i nie stanowiły ochrony dla przechowywanych w nich zbiorów w sytuacji ekstremalnej, jaką niewątpliwie stanowi wojna. Pozostawienie w nich zabytków, w razie szturmu, ostrzału artyleryjskiego czy bombardowania, mogło grozić ich zniszczeniem. Siedziba Muzeum, znajdująca się w tym czasie w Sukiennicach na Rynku Głównym, miała szklany dach osadzony na drewnianej konstrukcji. Pałac Czapskich przy ówczesnej ul. Wolskiej (obecnie Piłsudskiego), gdzie mieściło się Muzeum hr. Emeryka Hutten-Czapskiego (dalej: Muzeum Czapskich), i Dom Jana Matejki przy ul. Floriańskiej były w zasadzie budynkami o charakterze mieszkalnym. Gmach dawnego szpitala garnizonowego na wzgórzu wawelskim, gdzie znajdowały się składy magazynowe, również z założenia nie pełnił funkcji ochronnej. Niemniej jednak Kopera zdecydował się na dyslokację tylko $\mathrm{w}$ minimalnym zakresie i w większości pozostawił zbiory na miejscu ${ }^{5}$.

Zabezpieczenie oparto na dwóch grupach działań. Pierwszą było ukrycie najcenniejszych zabytków, drugą wyeksponowanie zbiorów o mniejszej wartości. W związku z tym opróżnione zostały galerie stałe, a w Sukiennicach pozostawiono obiekty mające niższą wartość artystyczna, określane jako „sztuka nowsza”, i tylko siedziba Muzeum była otwarta przez cały czas dla publiczności:

Z obrazów pozostałych w salach muzealnych urządzono galeryę obrazów od pocz[ątku] XIX w. do czasów obecnych, dostępnych dla publiczności po zniżonej cenie od 26 grudnia br. [1914]. Urządzenie wystawy było potrzebne nie tylko z tego powodu, że publiczność domagała się otwarcia, ale Komisya woyskowa, która zwiedzała zamknięte Muzeum oświadczyła kategorycznie, że sale na cele wojskowości zostana zajęte - o ile Muzeum funkcyonować nie będzie. Mając doświadczenie z Wawelem jakie szkody poczyniła nam woyskowość w gmachu przyszpitalnym nie chcieliśmy do tej ostateczności dopuścić, tembardziej że składy w Sukiennicach przepełnione są dziełami sztuki ${ }^{6}$.

\footnotetext{
${ }^{5}$ Kopera w sprawozdaniu przedkładanym władzom Krakowa w grudniu 1914 r. wspominał, że niektóre działania podejmowano już od sierpnia, a zgodnie ze Sprawozdaniem Dyrekcyi Muzeum Narodowego w Krakowie za rok 1914/15 całe przedsięwzięcie miało zająć „parę miesięcy”, zob. Archiwum Muzeum Narodowego w Krakowie (dalej: AMNK), Kancelaria Kopery, dp. 7248, Sprawozdanie z 31 XII 1914; F. Kopera, Sprawozdanie Dyrekcyi Muzeum Narodowego w Krakowie za rok 1914/15, Kraków 1916, s. 11. Przed 1915 Muzeum zarządzało jeszcze Barbakanem Bramy Floriańskiej, ponieważ jednak nie przechowywano i nie eksponowano tam obiektów, a ukrycie w nim zbiorów znajdujących się w innych budynkach wiązało się z koniecznością ich dyslokacji, lokalizacja ta nie była brana pod uwagę przez Koperę.

${ }^{6}$ AMNK, Kancelaria Kopery, dp. 7248, Sprawozdanie z 31 XII 1914.
} 
Z Domu Jana Matejki i z Muzeum Czapskich usunięto wszystkie obiekty, a oddziały zamknięto. Zakończono również ekspozycję czasowa poświęcona medalom, otwarta 28 VI 1914 przez krakowskie Towarzystwo Numizmatyczne?

W efekcie podjętych decyzji ukrytych zostało ok. 10 tys. najwartościowszych obiektów. Niestety nie posiadamy spisu zabytków uznanych wówczas za najcenniejsze, niemniej jednak możemy z dużym prawdopodobieństwem założyć, że głównym kryterium było datowanie - w Sukiennicach po ewakuacji zbiorów pozostała wzmiankowana wyżej „sztuka nowsza”. Jako szczególnie cenny potraktowano też cały zbiór numizmatyczny oraz dary przekazane Muzeum przez Edwarda Goldsteina, Stanisława Rusieckiego, Michała i Jadwigę Poleskich i wybrane malarstwo darowane przez rodzinę ze zbiorów po zmarłym w 1904 r. Edmundzie Łozińskim. Większość obiektów pochodzących z tych darów była typowana do dekoracji komnat zamku na Wawelu w związku z planowaną tam przed wojną lokalizacją krakowskiego Muzeum. Zbiór rycin zabezpieczono tylko w części, chroniąc najcenniejsze spośród nich. Podobnie postapiono z biblioteka, ukrywając woluminy z XV i XVI w. ${ }^{8}$

Zbiory schowano $\mathrm{w}$ czerech miejscach $\mathrm{w}$ budynkach muzealnych. Było to spowodowane koniecznościa przeprowadzenia właściwie całej akcji siłami pracowników Muzeum, pod presja czasu i przy braku dodatkowych środków finansowych. Kopera relacjonując przebieg prac, pisał:

\begin{abstract}
Ponieważ wydatki na te roboty [związane z zabezpieczaniem zbiorów] były znaczne (patrz zestawienie Dyreykcyi Muzeum Narodowego przedłożone Panu Dyrektorowi Magistratu w dniu 22 grudnia br.) a kredytu specjalnego na ten cel na razie uzyskać nie było można musiano posłużyć się funduszem płynącym z bieżących dochodów jak dochody za wstępy i garderobę. Ponieważ zaś fundusz ten z powodu zamknięcia Muzeum był nieznaczny, Dyrekcya zmuszoną była uciec się do niektórych firm z prośbą o kredyt. W krytycznem położeniu przyszła z pomoca instytucyi firma spedycyjna Leon Fremder i S-ka, która dostarczyła wozów, koni i własnych ludzi dla przewiezienia zbiorów na Wawel, co połączone było z wielkimi trudnościami. Zaznaczyć wypada, że w czasach dzisiejszych, gdzie brak koni wszędzie, a do wyciagnięcia wozu na wzgórze wawelskie dwóch par koni potrzeba, firma wspomniana oddała nam wielkie usługi. Wydatki na ten cel znajdą w znacznej mierze pokrycie w pozycyi budżetowej na r. 1914/15 „Przewóz zbiorów na Wawel”, o ile - naturalnie - kredyt ten nie będzie ograniczony. Inne firmy jak Halski, Gramatyka, Fischer i TS, również były nam pomocne nie odmawiajac nam kredytu9.
\end{abstract}

Decyzję o ukryciu danego obiektu podejmowano w wielu przypadkach „na gorąco", starając się w pierwszej kolejności zabezpieczyć obiekty o największej

\footnotetext{
${ }^{7}$ F. Kopera, op. cit., s. 10-11; „Monumentis Patriae...” Emerykowi Hutten-Czapskiemu w 110. rocznice śmierci Muzeum Narodowe w Krakowie, red. J. Skorupska, Kraków 2006, s. 41; J.S. Nowak, Marian Gumowski i jego spuścizna archiwalna w Muzeum Narodowym $w$ Krakowie, „Rocznik Polskiego Towarzystwa Heraldycznego” 2013, seria nowa, t. XII (XXIII), s. 166-167.
}

${ }^{8}$ F. Kopera, op. cit., s. 9, 11-12.

${ }^{9}$ AMNK, Kancelaria Kopery, dp. 7248, Sprawozdanie z 31 XII 1914. 
wartości. W dokumentach znajduje się wzmianka o planie prac zatwierdzonym przez prezydenta Krakowa Juliusza Leo, którego ogólne wytyczne znamy z pisma z października 1914, o czym niżej ${ }^{10}$.

Pierwszą lokalizacja, w której ukryto zbiory, były same Sukiennice. W pomieszczeniach zajmowanych przez Muzeum na piętrze budynku przygotowano dwie skrytki, gdzie zabezpieczono pastele i „najsubtelniejsze rysunki, rzeczy nadzwyczaj delikatne... [które] zamurowano w grubym murze piętrowej i sklepionej ubikacyi, zostawiając otwory wentylacyjne: [obiekty] przechowały się świetnie"11.

Druga grupę obiektów schowano w Muzeum Czapskich, gdzie przygotowano trzy skrytki. Pierwsza znajdowała się w jednym z pomieszczeń zlokalizowanych nad poziomem gruntu i w niej zabezpieczono typografię. Dwie kolejne skrytki umieszczono w piwnicach budynku. Znalazły się w nich „rzeźby drewniane, miniatury, tkaniny, porcelana, szkło, wyroby z metali, drzewa, kości, części broni, tysiące drobnych przedmiotów, mających wartość muzealna [które] starannie opakowano w bibułę, papier, watę, siano, wióra itp. i zabito w paki" ${ }^{2}$. Obiekty ukryte w Muzeum Czapskich zagrożone były głównie zawilgoceniem, ponieważ budynek znajduje się na terenie narażonym na podmakanie i zalanie. Kopera starał się zabezpieczyć śluzy zamykające kanały odpływowe oraz oczyścić szambo. „Sprawa jest bardzo pilna - pisał do służb miejskich - gdyż w suterynach tego gmachu nagromadziliśmy obecnie cenniejsze obiekty muzealne, dla zabezpieczenia ich przed uszkodzeniem na wypadek bombardowania twierdzy"13.

Ostatecznie jednej skrytki, w której ukryto porcelanę, szkło, broń i srebro, nie udało się uchronić przed mocnym zawilgoceniem. Kopera w Sprawozdaniu Dyrekcyi... pisał: „Oczywiście porcelanę i szkło pomieszczać można na krótki czas w wilgotnych pomieszczeniach bez szkody, uważać należy jednak, aby w takie miejsca nie kłaść klejonych sztuk, bo się rozkleja”, co niewątpliwie świadczy o tym, że taki przypadek uszkodzenia sklejonych obiektów znał z autopsji. Skrytki w piwnicach zostały zasypane ziemią i częściowo zamurowane, a wydobycie $\mathrm{z}$ nich obiektów po odsunięciu się frontu z okolic Krakowa było związane $\mathrm{z}$ usunięciem dwóch ścian i nadsypanych ośmiu fur ziemi ${ }^{14}$.

Najbardziej brzemienna w skutki okazała się decyzja dotycząca sposobu ukrycia monet z Muzeum Czapskich. W cytowanym już Sprawozdaniu Dyrekcyi... czytamy, że Gabinet Numizmatyczny na czas wojny został całkowicie zamknięty i rozpoczęto prace związane z zabezpieczaniem zbiorów. Pakowanie

${ }^{10}$ Ibidem, dp. 7248, Sprawozdanie z 31 XII 1914; ibidem, dp. 7237, Pismo z 8 X 1914.

11 F. Kopera, op. cit., s. 9. Zob. AMNK, Kancelaria Kopery, dp. 7327, Kosztorys z 17 V 1915.

12 AMNK, Kancelaria Kopery, dp. 7248, Sprawozdanie z 31 XII 1914.

${ }^{13}$ Ibidem, dp. 7308, Pismo z marca lub kwietnia 1915. Zob. ibidem, dp. 7327, Kosztorys z 17 V 1915.

${ }^{14}$ F. Kopera, op. cit., s. 8-9. Zob. AMNK, Kancelaria Kopery, dp. 7327, Kosztorys z 17 V 1915. 
obiektów, które zajęło „parę miesięcy”, polegało na tym, że każda moneta została owinięta w bibułkę, a następnie całą kolekcję umieszczono w beczkach wylanych terem. Kopera chwalił się nadzwyczajnym skutkiem takiej metody przechowania, gdyż „wilgoć nie tknęła nawet połysku nie będących nigdy w obiegu monet" ${ }^{15}$. W trakcie prac skoncentrowano się głównie na ochronie samego pojedynczego obiektu, pominięto natomiast całość działań związanych z zachowaniem nadawanego im układu, „a tem samem wieloletnia praca, porządkowanie i ułożenie monet i medali, zniweczone zostały"16.

W dużym stopniu decyzję Kopery może tłumaczyć wzmiankowane wyżej październikowe pismo Leo, w którym czytamy: „[...] najcenniejsze przedmioty Muzeum narodowego a przede wszystkiem zbiór monet i medali E[meryka] hr. Czapskiego mają być do dalekiej podróży spakowane. Gdy w chwili stosownej furgony automobilowe po zbiory zajada, wyda je Pan pełnomocnikowi upoważnionemu" 17 .

Ostatecznie do dyslokacji zbiorów nie doszło, a beczki zakopano w głębokich na dwa metry dołach pod podłogami pomieszczeń w Muzeum Czapskich, tak że ich wydobycie wiązało się z koniecznością stemplowania ścian, a potrzebnych było do tego sześciu pracowników zatrudnionych przez pięć dni ${ }^{18}$.

Ocenę postępowania Kopery w odniesieniu do zbioru numizmatycznego znajdujemy we Wspomnieniach... Mariana Gumowskiego, długoletniego kustosza i opiekuna tej kolekcji:

Tocząca się wówczas I wojna światowa nie ruszyła zupełnie ani mnie, ani Muzeum Czapskich. [...] Gdy w 1915 r. groziło niebezpieczeństwo oblężenia Krakowa, byliśmy wszyscy zaniepokojeni o zbiory, zwłaszcza numizmatyczne. Wtedy - nikomu nic nie mówiąc - dyrektor Kopera z woźnym Szkaradkiem wzięli pustą beczkę i wsypali po prostu do niej wszystkie monety i medale znajdujące się w szafie pancernej, a następnie zakopali beczkę w piwnicy pod pałacykiem. Mnie nie wtajemniczono umyślnie w tę sprawę, lecz powiedziano, że monety na czas wojny wywiezione zostały do Wiednia. Gdyby Kraków został zajęty i przyszła obca władza, miałem tylko tak odpowiadać.

Na szczęście nie doszło ani do oblężenia, ani do zajęcia Krakowa i nie było potrzeba rozpowszechniać bajeczki, którą tu od początku przeczuwałem. Front wojenny odsunął się daleko na wschód i groźba już nie wisiała nad Krakowem, a gdym się dowiedział prawdy, załamałem ręce, gdyż takie wsypywanie monet do beczki zniszczyło równocześnie cały porządek zbioru i lata całe trzeba było teraz pracy, aby pierwotny układ i porządek w szufladach zaprowadzićc ${ }^{19}$.

Trudno się dziwić tym słowom. Podjęte przez Koperę działania, chociaż determinowane na pewno lękiem o ochronę zbiorów i sprzecznymi wytycznymi odnośnie do docelowego miejsca ich ukrycia, spowodowały, że prace

${ }_{15}$ F. Kopera, op. cit., s. 8-11. Zob. AMNK, Kancelaria Kopery, dp. 7327, Kosztorys z 17 V 1915.

${ }^{16}$ F. Kopera, op. cit., s. 8-11.

${ }_{17}$ AMNK, Kancelaria Kopery, dp. 7237, Pismo z 8 X 1914.

${ }_{18}$ F. Kopera, op. cit., s. 8-11. Zob. AMNK, Kancelaria Kopery, dp. 7327, Kosztorys z 17 V 1915.

${ }_{19}$ M. Gumowski, Wspomnienia numizmatyka, Kraków 1965, s. 45. 
inwentaryzacyjne, które Gumowski prowadził przez ponad 15 lat, trzeba było rozpoczynać niemal od początku ${ }^{20}$.

Trzecią grupę zabytków schowano w gmachu poszpitalnym na Wawelu. Zbiory, zabezpieczone w skrzyniach umieszczonych na wiszacej podłodze i zasypane gruzem, ukryto $\mathrm{w}$ piwnicach, murując w nich skrytki. Tu zostały schowane rysunki, tkaniny i autografy ${ }^{21}$.

Ostatnią lokalizacją był sam Zamek Królewski na Wawelu, gdzie w dwóch skrytkach umieszczono walce z nawiniętymi obrazami m.in. Matejki, Siemiradzkiego i Chełmońskiego.

Obrazy cechowe, malowane tempera, zaklejono papierem, aby się podkład i farba nie kruszyły i nie odpadały, obrazy olejne na płótnie zdjęto z blejtramów i zwinięto na walce farbą na zewnątrz, przewijając je bibułką. Zajęły przeto niewiele miejsca. W wybranej przestrzeni walce zawieszono, poczem otwór zamurowano, zostawiając jednak na przestrzał wentyle. Tak przechowano między innymi „Hołd pruski”, „Pochodnie Nerona” i inne liczne obrazy olejne. W schowku znajdowały się one blisko dziesięć miesięcy i kiedy je wydobyto, były suche do tego stopnia, że nawet bibułka, w którą były owinięte, nie zawilgła, a o stęchliźnie mowy nie było ${ }^{22}$.

Aby móc wydobyć z ukrycia najcenniejsze dzieła, konieczne było wyburzenie kamiennej ściany osadzonej w cemencie oraz „wykopanie dojścia w dziedzińcu i rozbicie wewnętrznej ściany" zamku. Drugą skrytkę zlokalizowaną w głębokim na osiem metrów lochu zabezpieczono rumowiskiem $\mathrm{z}, 20$ fur”. $\mathrm{W}$ tym wypadku, prócz odgruzowania, konieczne było „usunięcie sztucznego sufitu zrobionego ze stukilkudziesięciu desek, belek, fosztów i ryg". Praca związana z wydobyciem z lochu pak z obiektami miała zająć ośmiu osobom pięć dni23.

Dla budynków wytypowanych do zabezpieczenia zbiorów zorganizowano straż. 7 XI 1914 przesłano do krakowskiego Magistratu spis pracowników Muzeum, którzy mieli w razie zagrożenia stanowić ochronę. Dla Sukiennic byli to: kustosz Józef Kwiatkowski, woźny Karol Wojas, palacz Franciszek Erdman i restaurator zabytków Ignacy Guziakiewicz. W Muzeum Czapskich opiekę sprawowali: Gumowski, woźny Michał Szkaradek i stróż Jan Faran.

${ }^{20}$ Informacja o dyslokacji zbiorów numizmatycznych podtrzymywana była przez Koperę do końca stanu zagrożenia. W Sprawozdaniu z 31 XII 1914 (AMNK, Kancelaria Kopery, dp. 7248) czytamy: „Wolno mi tutaj oznajmić, że część zbioru najcenniejsza (Kolekcya Czapskich) uratowana. Monety złote i srebrne zostały wywiezione z kraju i umieszczone w miejscu wiadomem p. Prez[ydentowi] miasta”. Na ten temat zob. też: M. Kocójowa, „Pamiatkom ojczystym ocalonym z burzy dziejowej”. Muzeum Emeryka Hutten-Czapskiego (Stańków-Kraków), Kraków 1978, s. 333; „Monumentis Patriae...”, s. 33; 41; J.S. Nowak, op. cit., s. 166-167.

${ }_{21}$ AMNK, Kancelaria Kopery, dp. 7327, Kosztorys z 17 V 1915; F. Kopera, op. cit., s. 8.

${ }^{22}$ F. Kopera, op. cit., s. 8. Zob. AMNK, Kancelaria Kopery, dp. 7248, Sprawozdanie z 31 XII 1914.

${ }^{23}$ AMNK, Kancelaria Kopery, dp. 7327, Kosztorys z 17 V 1915; zob. ibidem, Protokół z posiedzenia z 14 V 1915. 
W Domu Matejki na straży pozostali: kustosz Maciej Szukiewicz, woźny Roman Druszkiewicz i stróż Ignacy Dąbrowa. Zbiorów na Wawelu strzegli: dozorca Jan Bandt i stróż Stanisław Krupa. W przypadku ewakuacji kompleksu zamkowego osoby pilnujące składów miały być wzmocnione dodatkowo o Guziakiewicza i pełniącego funkcję urzędnika administracyjnego Józefa Pałasińskiego. Ogólna pieczę nad całością zadań sprawował Kopera wraz z Pałasińskim, który był odpowiedzialny za przechowanie i zabezpieczenie zbiorów oraz Kwiatkowskim, któremu powierzono koordynację prac związanych z pakowaniem i konserwacja. Zgodnie z pismem Kopery wymienione osoby mogły być skierowane również do ochrony zabytków poza budynkami Muzeum²4.

Podkreślić należy cel, w jakim straż została zorganizowana. W cytowanym już kilkakrotnie Sprawozdaniu z 31 XII 1914 Kopera nawiązywał do zagrożenia rabunkiem. Najpierw, odnosząc go do wojsk obcych, pisał:

Nadto pozostaje jeszcze do spakowania dział rycin, stare druki, zbiór fotografii i klisz, zbiór Goldsteina. Działu rycin, starych druków i biblioteki nie zamierzano pierwotnie pakować. Wobec jednak wywiezienia z Ossolineum zbioru rycin wraz z biblioteką Gwalberta Pawlikowskiego, biblioteki sieniawskiej i wielu innych, troska Dyrekcyi o te działy muzealne musiała spowodować ochronę tych zbiorów. Wprawdzie p. Wiceprezydent Szarski zają wobec Dyrektora Muzeum Narodowego takie stanowisko, że Muzeum Narodowe nie posiada arcydzieł, któreby były pożądane dla zbiorów rosyjskich, jednakże fakty dzisiaj już liczne nie potwierdziły tej opinii, z drugiej zaś strony zaprzeczyć się nie da, że zbiory Muzeum Narodowego są najbogatszą skarbnica twórczości artystycznej i kultury całego narodu, że utrata tych zbiorów byłaby wielką narodową klęską. Toteż personel Muzeum Narodowego nie tylko w dzień ale i nocami pracował z wytężeniem tem intenzywniejszem, im bliżej było niebezpieczeństwo ${ }^{25}$.

Kilka akapitów niżej dementował zasadność rozważania zagrożenia rabunkiem ze strony rodaków:

P[an] Prezydent miasta uznał za stosowne, ażeby nie wtajemniczać wielkiej liczby osób w plany dyzlokacyi zbiorów. Nie chodzi tu o grabież.

[...] pewna część zbiorów została rozmieszczona w gm[achu] poszp[italnym] na Wawelu, a to nie tyle z obawy przed rabunkiem, ile z tego powodu, ze sufit w Suk[iennicach] jest szklany. Na Wawel[u] budynek jest sklepiony ${ }^{26}$.

Faktem pozostaje, że do ochrony ukrytych zbiorów zostali zmobilizowani wszyscy pracownicy Muzeum obecni wówczas w Krakowie. Szczupłe

${ }^{24}$ Ibidem, dp. 7234, Pismo z 7 XI 1914; ibidem, dp. 7245, Pismo z 4 XII 1914; ibidem, dp. 7248, Sprawozdanie z 31 XII 1914. Na temat pracowników Muzeum zob. J. Skorupska-Szarlej, Rejestr pracowników Muzeum Narodowego w Krakowie, cz. 1: Do roku 1950, Kraków 2004, passim.

${ }^{25}$ AMNK, Kancelaria Kopery, dp. 7248, Sprawozdanie z 31 XII 1914.

${ }^{26}$ Ibidem, dp. 7248, Sprawozdanie z 31 XII 1914; zob. ibidem, Protokół z 19 XII 1914; ibidem, dp. 7309, Rozliczenie wydatków związanych z zabezpieczeniem zbiorów. 
siły prawdopodobnie nie byłyby $\mathrm{w}$ stanie poradzić sobie ani z odparciem ataku większej grupy rabusiów, ani z uratowaniem zbiorów przed ogniem w przypadku pożaru wywołanego bombardowaniem. Ich zadanie polegało raczej na „widocznej obecności” oraz w razie realnego zagrożenia alarmowaniu odpowiednich służb miejskich. Na szczęście przez cały okres, kiedy zbiory pozostawały w ukryciu, nie pojawiła się taka konieczność.

Największe zagrożenie odczuwalne było w Krakowie w pierwszych dniach grudnia 1914. Już zatem w sytuacji nieco spokojniejszej, bo w drugiej połowie tego miesiąca w Sukiennicach zebrała się nadzwyczajna komisja, której zadanie stanowiła ocena prac przeprowadzonych przy zabezpieczaniu zbiorów muzealnych. Wizytujacy Muzeum wiceprezydent Krakowa Ernest Bandrowski i starszy radca budownictwa miejskiego Jan Zawiejski skontrolowali pomieszczenia na pierwszym piętrze oraz zobowiązali Koperę do sprawozdania się z podjętych działań ${ }^{27}$.

Ostatniego dnia grudnia 1914 trafiło na ręce Bandrowskiego „Sprawozdanie z robót przeprowadzonych przez Dyrekcyę Muzeum Narodowego celem zabezpieczenia zbiorów powierzonych jej opiece”. Kopera przedstawił w nim dotychczasowy przebieg prac oraz zaznaczył, że zabezpieczeniem należy objąć zbiory militariów, rysunki i dział etnograficzny ${ }^{28}$. W dokumentach nie odnalazłam wzmianek na temat prowadzonych po grudniu 1914 prac związanych z pakowaniem obiektów.

14 V 1915 odbyło się posiedzenie Komisji, w której skład weszli Leo, Bandrowski, Zawiejski, radca Budownictwa Miejskiego Andrzej Kłeczek, historycy sztuki Józef Jakub Muczkowski i Stanisław Tomkowicz oraz Kopera. Uzgodniono, że ze względu na zmienioną sytuację polityczną związaną z przesunięciem się frontu oraz odsunięciem zagrożenia wojennego od Krakowa należy wydobyć ukryte zbiory muzealne. Cała akcja została przeprowadzona niezwykle szybko i przy czynnym udziale władz miasta. Już pod koniec czerwca Magistrat zaakceptował kosztorysy. Kopera ograniczył do maksymalnie dwóch tygodni urlopy kustoszy: Szukiewicza, Kwiatkowskiego i Gumowskiego, odpowiedzialnych za rozlokowanie wydobytych zbiorów, a swój i Pałasińskiego zdecydował wykorzystać po zakończeniu wojny. Pod koniec lipca, czyli niecałe dwa i pół miesiąca później, Kopera prosił o ponowne zwołanie komisji, która miałaby ocenić obecny stan zbiorów ${ }^{29}$.

Ogromny pośpiech, widoczny przy działaniach związanych z wydobyciem ukrytych obiektów, wiązał się z obawą przypisaną w protokole Tomkowiczowi, że „przechowywanie [...] zbyt długie dzieł sztuki, choćby w najlepszych lokalach, jest zawsze szkodliwe”. Można domniemywać, że Kopera wolałby, aby

\footnotetext{
${ }^{27}$ Ibidem, dp. 7248, Protokół z 19 XII 1914.

${ }^{28}$ Ibidem, Sprawozdanie z 31 XII 1914.

${ }^{29}$ Ibidem, dp. 7327, Decyzja Magistratu z 24 VI 1915; ibidem, dp. 7340, Plan urlopów z 15 VI 1915; ibidem, dp. 7365, Projekt pisma do Bandrowskiego z 29 VII 1915.
} 
ukryte zbiory pozostały w schowkach, aż do oficjalnego zakończenia wojny, niemniej jednak decyzji władz miasta nie mógł się sprzeciwićc ${ }^{30}$.

Brak zaufania władz zwierzchnich do podjętych działań na rzecz zabezpieczenia zbiorów sprawił Koperze wielka przykrość. Widoczne jest to w projekcie pisma dotyczącym zwołania Komisji dla oceny stanu wydobytych z ukrycia zabytków. W liście do Bandrowskiego pisał:

\begin{abstract}
Zbiory Muzeum Narodowego zostały z powrotem wydobyte i rozłożone. Proszę o zwołanie Komisyi, któraby przekonała się o stanie zbiorów zwłaszcza ponieważ na posiedzeniu zwołanej przez Ekscellencyę Komisyi w połowie maja br. P. Nadradca Zawiejski wykazał możliwość zjedzenia zbiorów przez szczury, myszy oraz zniszczenia ich przez wilgoć. Wobec tego ciekawem będzie dla Komisyi jak zachowały się przedmioty pomieszczone przez nas $\mathrm{w}$ zamurowanych lub zasypanych miejscowościach a nawet zakopane w wilgotnej ziemi, jak wyszły z lochu takie skarby jak Hołd pruski, Kościuszko pod Racławicami i czy nie oksydowały monety i medale kilkumilionowej wartości, jak wyszły subtelne tkaniny, akwarele i pastele.

Wobec obaw żywionych przed wydobyciem przedmiotów mogę przypuścić, że Komisya przejrzy wydobyty materiał ${ }^{31}$.
\end{abstract}

Projekt listu Kopery został przez Bandrowskiego skrócony do słów: „Zbiory Muzeum Narodowego zostały z powrotem wydobyte i odpowiednio umieszczone. Proszę o zwołanie Komisyi, któraby przekonała się o stanie zbiorów" i prawdopodobnie w tej formie przesłany jako zawiadomienie do uczestników spotkania $^{32}$.

Nie udało się ustalić, czy komisja, o której zwołanie prosił Kopera, spotkała się i czy oceniła stan zbiorów Muzeum. Niemniej w Sprawozdaniu Dyrekcyi... Kopera zanotował, że obrazy, w tym cechowe i malowane tempera oraz olejne, po wydobyciu ze schowków były suche i bez zapachu stęchlizny. Obiekty z metalu i monety, pomimo że ukryte pod ziemia, wydobyto niezardzewiałe i błyszczące. Bez uszkodzeń przechowały się również pastele, rysunki, porcelana i szkło czy tkaniny. Kopera pisał: „Wystawione obecnie wystapiły w całej okazałości i świadczą najlepiej, że Zarząd Muzeum postapił ostrożnie i skarby te zagrożone bez uszkodzenia w świetnym stanie oddał społeczeństwu" ${ }^{33}$.

Trudno jednoznacznie ocenić działania podjęte w celu zabezpieczania zbiorów w 1914. Zabytki, poza wspomnianymi wyżej uszkodzeniami powstałymi na sklejanej z fragmentów porcelanie i szkle, przechowały się bardzo dobrze, a prowizoryczne opakowania i naprędce aranżowane schowki doskonale spełniły swoją rolę. Natomiast brak poszanowania dla nadawanego przez lata układu zbiorów podczas ich pakowania - głównie w odniesieniu

\footnotetext{
${ }^{30}$ Ibidem, dp. 7327, Protokół z 14 V 1915.

${ }^{31}$ Ibidem, dp. 7365, Projekt pisma do Bandrowskiego z 29 VII 1915.

${ }^{32}$ Ibidem.

${ }^{33}$ F. Kopera, op. cit., s. 8.
} 
do numizmatów i zbiorów bibliotecznych - okazał się fatalny w skutkach. Przemieszanie układu spowodowało, że prace nad ponownym udostępnieniem obiektów publiczności trwały przez wiele kolejnych lat, a otwarcie Muzeum Czapskich nastapiło dopiero w marcu 1919. Rozgoryczenie, jakie odczuwał Gumowski, widoczne było jeszcze wiele lat później, kiedy spisując swoje wspomnienia, zanotował: „Cała ta sprawa wpłynęła na mnie tak deprymująco, że w 1919 uległem namowie i opuściłem Muzeum Czapskich”. Chociaż wiemy, że decyzja o objęciu funkcji dyrektora Muzeum Wielkopolskiego spowodowana była również innymi czynnikami, nie można bagatelizować wpływu, jakie miało na nią zmarnowanie wielu lat żmudnej pracy poświęconej przez niego tej kolekcji ${ }^{34}$.

\section{Zabezpieczenie zbiorów przed II wojną światową}

Perspektywa kolejnego konfliktu skłaniała osoby odpowiedzialne za dziedzictwo kulturowe do podejmowania działań majacych na celu zabezpieczenie powierzonych im zbiorów. Kustosze muzeów w całej Europie, rozumiejąc ogrom zniszczeń po I wojnie światowej, starali się doprowadzić do zagwarantowania ochrony zbiorów narodowych. Najwcześniej, bo już w 1929 na problem braku zabezpieczeń muzeów na wypadek działań wojennych uwagę zwrócili Holendrzy, po nich w 1933 Brytyjczycy. Wojna domowa w Hiszpanii w latach 1936-1939, podczas której użyto nowych rodzajów broni oraz nowych technik walki, jak np. ataki bombowe, sprecyzowała zakres najważniejszych zagrożeń.

W największych muzeach brytyjskich i francuskich przygotowywane były formalne plany na wypadek wojny. Zadecydowano, że najcenniejsze zbiory zostana przewiezione na takie terytoria tych państw, na których nie przewidywano prowadzenia zmasowanych działań wojennych. Przygotowania do ewakuacji obejmowały m.in. wytypowanie najcenniejszych zabytków oraz wykonanie szczegółowych list, znalezienie lokalizacji dla ewakuowanych zbiorów, zgromadzenie materiałów do pakowania oraz zabezpieczenie budynków ${ }^{35}$.

Również w Polsce podjęto działania w tym kierunku. 16 IV 1938 lwowskie koło Związku Bibliotekarzy Polskich wystosowało do instytucji gromadzących zbiory archiwalne, biblioteczne i muzealne, w tym i do Muzeum, dziewięciopunktowa ankietę. Formularz ten miał pozwolić na zebranie informacji dotyczących „dotychczasowych przygotowań polskich instytucji kulturalnych (archiwów, bibliotek i muzeów) na wypadek wojny. [...] Zebrane informacje - pisano dalej - posłużą czynnikom fachowym do opracowania odpowiednich wskazówek,

\footnotetext{
${ }^{34}$ M. Gumowski, op. cit., s. 45-46. Zob. AMNK, Kancelaria Kopery, dp. 8696, Pismo z 4 III 1919 w sprawie opóźnienia otwarcia Muzeum Czapskich; M. Kocójowa, op. cit., s. 333-334.

${ }^{35}$ Zob. L.H. Nicholas, Grabież Europy. Losy dziet sztuki w Trzeciej Rzeszy i podczas II wojny światowej, tłum. B. Sławomirska, Kraków 1997, s. 51-58.
} 
ramowej instrukcji, oraz ogólnego planu ochrony w czasie ewentualnej wojny, najcenniejszych zabytków przechowywanych w polskich instytucjach"36. Kopera odpowiedział na pismo niezwykle szybko, bo już tydzień później, odsyłając ponad dwustronicowy dokument. Wyłaniajacy się jednak na podstawie kwestionariusza obraz zabezpieczeń Muzeum ukazywał ogromne braki w tym zakresie.

Zbiory instytucji znajdowały się w dziewięciu lokalizacjach ${ }^{37}$, z których tylko Muzeum Czapskich w pewnej części spełniało standardy ochrony zbiorów. Pozostałe budynki - w mniejszym lub większym stopniu - nadal jedynie przystosowywano do celów muzealnych - wystawienniczych czy magazynowych. Niedogodne było również położenie budynków względem potencjalnych celów ataku. Oddział im. Erazma Barącza sąsiadował z koszarami policji, a pozostałe lokalizacje znajdowały się w obrębie Plant. Kopera pisał:

[...] obszar ten śródmieścia w razie ataku lotniczego, szczególnie z wielkiej wysokości, będzie przedstawiał stosunkowo nieznaczny obszar docelny dla rzucanych bomb, przez co celność bomb staje się problematyczna, to wszystkie budynki muzealne znajduja się w obrębie zagrożenia z powodu poczty, dworca, siedlisk władz administracyjnych. Co do magazynu w Podgórzu - to zagraża mu bliskość gazowni i elektrowni ${ }^{38}$.

Dodatkowy czynnik negatywnie wpływający na sytuację zbiorów w razie ataku bombowego stanowiło także wyposażenie wnętrz, na które składały się drewniane podłogi, stropy i drzwi. Schody również w większości wykonane były z drewna, za wyjątkiem Sukiennic i Muzeum Czapskich, gdzie zastosowano kamień. Specjalistyczne sejfy zabezpieczajace przed pożarem czy innymi zniszczeniami „wpuszczone w mur do przechowywania numizmatów” znajdowały się tylko w Muzeum Czapskich. Pozostałe meble - gabloty, czy to wykonane z metalu, czy twardego drewna, posiadały duże przeszklone płaszczyzny, w żaden sposób nie zabezpieczając zbiorów. Wyposażenie przeciwpożarowe stanowiły gaśnice, natomiast wewnętrzne hydranty z parcianymi wężami znajdowały się jedynie w Sukiennicach i w magazynach na Podgórzu.

${ }^{36}$ AMNK, Kancelaria Kopery, dp. 172/38, Pismo Koła Lwowskiego Związu Bibliotekarzy Polskich z 16 IV 1938. Działania poświęcone zabezpieczeniu zbiorów na wypadek wojny MWRiOP podejmowało już od 1938, zob. AAN, MWRiOP, sygn. 7054, k. 128-347; B. Mansfeld, Muzea na drodze do samoorganizacji. Zwiazek Muzeów w Polsce 1914-1951, Warszawa 2000, s. 119.

${ }^{37}$ Muzeum w 1938 r. posiadało siedzibę w Sukiennicach na Rynku Głównym oraz oddziały: Wieżę Ratuszową również na Rynku Głównym, Muzeum Jana Matejki, Muzeum Czapskich, Oddział im. Erazma Baracza przy ul. Karmelickiej 51, Oddział im. Feliksa Jasieńskiego przy ul. Szczepańskiej 11 oraz magazyny na Rynku Podgórskim i w budynku poszpitalnym na Wawelu. W 1939 oddano część Nowego Gmachu - projektowanego i budowanego specjalnie na cele muzealne. W chwili wybuchu II wojny światowej nie był on jednak jeszcze wykorzystywany przez Muzeum na cele ekspozycji.

${ }^{38}$ AMNK, Kancelaria Kopery, dp. 172/38, Pismo do Koła Lwowskiego Zwiąku Bibliotekarzy Polskich z 22 IV 1938. 
Wszyscy pracownicy Muzeum zostali przeszkoleni w zakresie obrony przeciwlotniczej, jednak dla znacznej części z nich było to szkolenie tylko teoretyczne. W chwili przygotowywania odpowiedzi na ankietę, czyli w kwietniu 1938, planów ewakuacji najcenniejszych obiektów jeszcze nie przygotowano, nie wytypowano także tych eksponatów, które w pierwszej kolejności należało zabezpieczyć. Na pytanie: „czy opracowano podział zbiorów na kategorie wedle ich ważności i wartości oraz możliwości zniszczenia?”, Kopera udzielił enigmatycznej odpowiedzi o ustaleniu ogólnych zarysów. Rozumiejąc jednak konieczność wszczęcia starań o ochronę powierzonych swojej pieczy zbiorów, zakładał koncentrację podejmowanych wysiłków na budowie schronu, który ostatecznie powstał w piwnicach Nowego Gmachu przy al. 3 Maja 1, oraz przygotowaniu pracowników Muzeum, którzy mieli zabezpieczyć zbiory z zachowaniem obowiązujących wówczas wytycznych konserwatorskich ${ }^{39}$.

Akcja bibliotekarzy lwowskich była w zasadzie pierwszym działaniem prowadzonym w celu przede wszystkim uświadomienia coraz bardziej prawdopodobnego zagrożenia wojennego. Niezamierzonym dodatkowym efektem stało się wykazanie niemal całkowitego braku polityki zabezpieczenia zbiorów sztuki - w tym muzealiów - w obliczu ewentualnych działań wojennych.

Kolejna akcję, tym razem o charakterze lokalnym, zainicjowało Towarzystwo Miłośników Historii i Zabytków Krakowa. W dokumencie z października 1938, skierowanym do krakowskiego Magistratu, zgłoszono postulat powołania specjalnej komisji, która miała „obmyślić” środki dla zabezpieczenia zabytków przed skutkami działań wojennych. Magistrat, chociaż działający nieco opieszale, wykazał się pełnym zrozumieniem dla zgłoszonego problemu. W przesłanej niemal pięć miesięcy później odpowiedzi czytamy:

Sprawa ochrony pamiątek i zabytków przeszłości na wypadek działań wojennych, a zwłaszcza nalotów bombowych, stanowi już od dawna szczerą troskę Zarządu Miejskiego. Jest bowiem rzeczą niepodlegającą wątpliwości, że historyczne zabytki Krakowa, stanowiące obecnie główne dobro materialne i moralne miasta, a zarazem jeden z najważniejszych tytułów znaczenia jego pośród innych miast polskich, ponieść mogą w wypadku akcji wojennej, niepowetowane straty. Zarząd Miejski zdaje sobie przy tym sprawę z tego, że pomyślne posunięcie sprawy zabezpieczenia krakowskich zabytków i zbiorów na czas wojny, wymaga uzgodnionej i planowej współpracy ze strony szeregu czynników, jak władz kościelnych i administracyjnych, czynników konserwatorskich, wojskowości, sfer muzealnych oraz tych organizacyj i kół obywatelskich, które postawiły sobie za zasadę szerzenie miłośnictwa i kultu dla drogocennych dokumentów przeszłości ${ }^{40}$.

Jednocześnie wskazano jako instytucję kompetentną do prowadzenia tej sprawy Wojewódzki Urząd Konserwatorski, ze swojej strony oferując

${ }^{39}$ AMNK, Kancelaria Kopery, dp. 172/38, Pismo do Koła Lwowskiego Związku Bibliotekarzy Polskich z 22 IV 1938.

40 AAN, MWRiOP, sygn. 7054, Zarząd Miejski do Zarządu Towarzystwa Miłośników Historii i Zabytków Krakowa z 17 II 1939, odpis, k. 298. 
pełne poparcie dla inicjatywy i aktywną współpracę w ramach zaproponowanej komisji. Korespondencja ta została kilka dni później przesłana przez Towarzystwo do Oddziału Sztuki i Kultury krakowskiego Urzędu Wojewódzkiego ${ }^{41}$.

$\mathrm{Na}$ forum ministerialnym temat zabezpieczenia zabytków na wypadek działań wojennych stał się palącym problemem ok. kwietnia 1939. Było to skutkiem indywidualnych monitów kierowanych przez dyrektorów instytucji przechowujacych zbiory archiwalne, biblioteczne i muzealne ${ }^{42}$.

W odpowiedzi na dwie ustawy z 30 III 1939 - o powszechnym obowiązku świadczeń rzeczowych oraz o wycofaniu urzędów, ludności i mienia z zagrożonych obszarów państwa, Ministerstwo Wyznań Religijnych i Oświecenia Publicznego (dalej: MWRiOP) skierowało do Ministerstwa Spraw Wojskowych (dalej: MSWojsk.) pismo poruszające różne aspekty tej kwestii. Wśród najważniejszych dezyderatów wskazywano: zwolnienie instytucji gromadzacych zbiory z obowiązku świadczeń wojennych, zorganizowanie i wyposażenie drużyn specjalnych ratowniczych oraz oznakowanie obiektów zabytkowych nieruchomych, np. warszawskiej kolumny Zygmunta III Wazy, pomników Mikołaja Kopernika i ks. Józefa Poniatowskiego, Zamku Królewskiego i katedry na Wawelu oraz kościoła Mariackiego w Krakowie. W odniesieniu do zabytków ruchomych: „archiwów, bibliotek, muzeów, zbiorów publicznych i prywatnych, skarbów kościelnych oraz cenniejszych zabytków sztuki należących do instytucyj i korporacyj publiczno-prawnych i osób prywatnych" zaznaczano potrzebę podjęcia dwutorowych działań. Na podstawie spisów najcenniejszych zabytków, których wykonanie planowano na kolejne miesiące, zakładano ich podział na dwie grupy - wycofywaną na tereny „bezpieczne” oraz podlegajaca zabezpieczeniu na miejscu. Ochrona zabytków poddanych wycofaniu miała polegać na zorganizowaniu grup, które ewakuowałyby wytypowane zbiory z terenów zagrożonych, stworzeniu komisji konserwatorskich opiekujących się tymi zabytkami oraz przygotowaniu budynków, w których winny one zostać umieszczone. Natomiast zabytki wskazane do zabezpieczenia na miejscu miały podlegać opiece przydzielonych do sztabów wojskowych konserwatorów, którzy otrzymaliby także prawo do wyboru kolejnych cennych obiektów ze względu na zagrożenie podlegajacych ewakuacji ${ }^{43}$.

${ }^{41}$ AAN, MWRiOP, sygn. 7054, Zarząd Miejski do Zarządu Towarzystwa Miłośników Historii i Zabytków Krakowa z 17 II 1939, odpis, k. 298; zob. też: ibidem, Zarząd Towarzystwa Miłośników Historii i Zabytków Krakowa do Zarządu Miejskiego z 3 X 1938, odpis, k. 298; ibidem, Zarząd Towarzystwa Miłośników Historii i Zabytków Krakowa do krakowskiego Urzędu Wojewódzkiego z 27 II 1939, k. 299. Wybór dokumentów o ochronie zabytków na wypadek wojny zob. Przygotowanie obronne państwa 1935-1939, cz. 1: Prawo i administracja, seria: „Wojskowe Teki Archiwalne”, t. VI, Warszawa 2014, s. $468-483$.

${ }^{42}$ C. Skuza, Wojenne i powojenne losy skarbów narodowych, Toruń 1994, s. 30-31.

${ }^{43}$ AAN, MWRiOP, sygn. 7054, Pismo do Ministra Spraw Wojskowych z 27 IV 1939, k. 318-320. Projekt powołania instytucji konserwatorów przy Komisarzach Cywilnych był także treścią 
Akta MWRiOP zawierają jedenastopunktowy kwestionariusz sporządzony prawdopodobnie w połowie 1939, na podstawie którego miano ocenić stan i zakres przygotowania muzeów do wojny. Pytania dotyczyły przeszkolenia pracowników z zakresu obrony przeciwlotniczej i wydanych wewnętrznych rozporządzeń oraz współpracy z władzami lokalnymi, zabezpieczenia przeciwpożarowego, a także prac technicznych, w tym przygotowania schronu lub zabezpieczających pomieszczeń czy zgromadzenia specjalistycznych opakowań ewakuacyjnych. W ankiecie pytano również o zapotrzebowanie na materiały zabezpieczające, liczbę zabytków wskazanych jako szczególnie cenne i tym samym przewidziane do ewakuacji, podano również wytyczne, jak taką selekcję należy przeprowadzić. Proszono o informacje na temat zabezpieczenia ewidencji zbiorów oraz czy w razie potrzeby instytucja będzie $\mathrm{w}$ stanie przyjąć w depozyt wyjątkowo cenne kolekcje prywatne ${ }^{44}$.

W maju 1939 MWRiOP zwróciło się do Oddziału Sztuki w Komisariacie Rządu o wskazanie zabytków sztuki o charakterze nieruchomym, które ze względu na wartość „powinny być chronione od pocisków i bomb za pomoca specjalnych urządzeń technicznych, jak: worki z piaskiem, rusztowania, obmurowania, siatki, materace itp." ${ }^{45}$ Sprecyzowanie zasad i kolejności zabezpieczania i ewakuacji muzeów stanowiło również temat konferencji zorganizowanej przez Towarzystwo Opieki nad Zabytkami Przeszłości, która odbyła się 27 czerwca w Instytucie Propagandy Sztuki ${ }^{46}$.

Natomiast XV Zjazd Delegatów Związku Muzeów w Polsce, który miał miejsce w ostatnich dniach czerwca 1939 w Gdyni, poświęcony został problemowi technicznych procedur zabezpieczenia obiektów. Referat Eugeniusza

pisma MWRiOP do Głównego Komisarza Cywilnego z września 1939, zob. ibidem, pismo do Głównego Komisarza Cywilnego z września 1939, k. 328-329, ibidem, Rozporządzenie Głównego Komisarza Cywilnego o organizacji ochrony zabytków na obszarze operacyjnym (brulion), [b.d.], k. 330; ibidem, Projekt instrukcji dla konserwatorów działających przy Komisarzach Cywilnych, [b.d.], k. 331-332. W zakresie ustawodawstwa dotyczącego ochrony zabytków zob. Ustawa z 30 marca 1939 powszechnym obowiązku świadczeń rzeczowych (Dz.U. 1939, nr 30, poz. 200) oraz Rozporządzenie Ministrów Spraw Wojskowych, Spraw Wewnętrznych, Spraw Zagranicznych, Skarbu, Wyznań Religijnych i Oświecenia Publicznego, Rolnictwa i Reform Rolnych, Przemysłu i Handlu, Komunikacji, Opieki Społecznej oraz Poczt i Telegrafów z dnia 26 sierpnia 1939 r. w sprawie wykonania Ustawy o powszechnym obowiązku świadczeń rzeczowych (Dz.U. 1939, nr 81, poz. 529); Ustawa z 30 marca 1939 o wycofaniu urzędów, ludności i mienia z zagrożonych obszarów państwa, zakładających przymusową ewakuację mienia przedstawiającego wartość naukowa, artystyczną lub historyczna, a w razie braku możliwości ewakuacji zewidencjonowanie i zabezpieczenie na miejscu (Dz.U. 1939, nr 29, poz. 197), zob. też: I. Bujniewicz, Ogólne zasady wycofania i rozmieszczenia mienia i ludzi na wypadek wojny z Niemcami w okresie międzywojennym, „Przegląd Kwatermistrzowski” R. XIII, 1962, z. 2, s. 105-109; J. Pruszyński, Dziedzictwo kultury Polski. Jego straty i ochrona prawna, t. I, Kraków 2001, s. 405-406.

${ }^{44}$ AAN, MWRiOP, sygn. 7054, Kwestionariusz, [b.d.], k. 326-327.

${ }^{45}$ Ibidem, Pismo do Oddziału Sztuki Komisariatu Rządu z 10 V 1939, k. 338.

46 J. Pruszyński, op. cit., s. 406. 
Tora, dyrektora Miejskiego Muzeum Przemysłowego w Krakowie, pt. Zabezpieczenie zbiorów muzealnych na wypadek wojny, wywołał niezwykle ożywiona dyskusję. Podczas obrad zwrócono uwagę przede wszystkim na problem dalszego braku jakichkolwiek wytycznych rządowych do zabezpieczenia zbiorów. Wśród zagrożeń, prócz zniszczeń wywołanych działaniami wojennymi, wymieniono również możliwe działania rabunkowe, w tym polskiej armii, postulując, aby MSWojsk. wydało żołnierzom rozkazy mające na celu ochronę zbiorów ${ }^{47}$.

Efektem zjazdu było wystosowanie pisma do Wydziału Sztuki MWRiOP „z prośbą o jak najrychlejsze spowodowanie rozesłania do wszystkich muzeów instrukcji w sprawie pogotowia i zabezpieczenia zbiorów na wypadek wojny" 48 . Dodatkowo nakładem Związku ukazała się broszura Zabezpieczenie zbiorów muzealnych na wypadek wojny. Referaty na XV-ty Zjazd Zwiazku Muzeów $w$ Polsce odbyty $w$ Gdyni $w$ dniach 24-27 czerwca 1939, zawierająca cztery z pięciu wygłoszonych na Zjeździe wystapień oraz Program prac zmierzajacych do zabezpieczenia zbiorów muzealnych na wypadek wojny ${ }^{49}$. Broszura została rozesłana do wszystkich zrzeszonych w Związku muzeów.

W krakowskim muzeum podjęto decyzję o zabezpieczeniu większości zbiorów na miejscu, ukryciu w schronie w Nowym Gmachu najcenniejszych zabytków oraz wywiezieniu jednego obrazu - Hotdu pruskiego ${ }^{50}$. Decyzja podyktowana była przede wszystkim ogromną już wówczas liczbą zbiorów, szacowaną na ok. 150 tys. pozycji inwentarzowych. Ponadto Kopera, mający w pamięci przecież nie tak dawne wydarzenia z I wojny światowej, mógł zakładać i tym razem podobny przebieg wypadków. W Sprawozdaniu Dyrekcji... napisał: „Wojna wybuchła nagle. Jednakże sytuacja polityczna

${ }^{47}$ AMNK, sygn. ZMP 26, Materiały dotyczące XV Zjazdu w Gdyni 1939, „Notatki i załączniki ze zjazdu w Gdyni” 24-27 VI 1939; ibidem, sygn. ZMP 27 - Materiały dotyczące XVI Zjazdu w Krakowie 1945, protokół.

${ }^{48}$ Ibidem, sygn. ZMP 26, Pismo do MWRiOP z 5 VII 1939.

${ }^{49} \mathrm{~W}$ tomie pt. Zabezpieczenie zbiorów muzealnych na wypadek wojny. Referaty na XV-ty Zjazd Zwiazku Muzeów w Polsce odbyty w Gdyni w dniach 24-27 czerwca 1939, Kraków 1939, opublikowano: E. Tor, Zabezpieczenie zbiorów muzealnych na wypadek wojny. Streszczenie referatu wygtoszonego w Gdyni na XV Zjeździe Delegatów Zwiazku Muzeów $w$ Polsce, s. 3-8; A. Kietlińska, Zagrożenie muzeów i zbiorów muzealnych w czasie wojny, s. 9-10; J. Przeworska, Ochrona zbiorów muzealnych na wypadek wojny, s. 11-14; W. Ber, Pogotowie administracyjne i personalne muzeów na wypadek wojny, s. 15-17; Program prac zmierzajacych do zabezpieczenia zbiorów muzealnych na wypadek wojny, s. 18-19. Referatu M. Gozdowskiego, Obrona przeciwpożarowa muzeów na wypadek wojny, ponieważ „podaje środki dostatecznie znane kierownikom muzeów”, postanowiono nie drukować zob. AMNK, sygn. ZMP 26, Materiały dotyczące XV Zjazdu w Gdyni 1939; ibidem, ZMP 3, Dziennik podawczy z lat 1937-1940, poz. 508/39.

${ }^{50} \mathrm{Na}$ temat losów wojennych Hotdu pruskiego Jana Matejki zob. „Hołd pruski” w Zamościu - wojenne dzieje obrazu. Ze wspomnień Eugeniusza Tora, oprac. do druku Z. Żygulski jun., „Rozprawy Muzeum Narodowego w Krakowie. Seria Nowa” 1999, t. I, s. 129-139; W. Staniszewski, O tych co uratowali „Hotd pruski”, http://www.robertkusmierz.com/zamosc/ zamosc.php?d=wydarzenia\&a=hold_pruski (dostęp: 19 IV 2016). 
ukształtowała się dla Krakowa inaczej, aniżeli dla Belgii lub Paryża. W Belgii niejedno dzieło sztuki zniszczało [...]. W Paryżu niebezpieczeństwo również zaskoczyło zarząd muzeum"

Konsekwencję decyzji o pozostawieniu zbiorów w Krakowie stanowiło podjęcie starań o jak najlepsze przygotowanie budynków muzealnych na wypadek ataku lotniczego i pożaru. Działania te były zbieżne z polityką władz państwowych i miasta, koncentrującą się właśnie na tym rodzaju zagrożenia ${ }^{52}$.

W Krakowie jesienią 1938 przeprowadzono próbne alarmy przeciwlotnicze oraz ćwiczenia na całkowite zaciemnienie miasta. Pod koniec marca 1939 miejska rozgłośnia radiowa wyemitowała serię pogadanek edukacyjnych poświęconych obronie przeciwlotniczej i przeciwgazowej, które towarzyszyły ogłoszonemu w tym samym czasie werbunkowi do miejskich ochotniczych służb obrony przeciwlotniczej i przeciwgazowej. Odwołując się do uczuć patriotycznych, liczono także na ofiarny udział społeczeństwa w zakresie ochrony i zabezpieczania zbiorów sztuki.

Ochrona zabytków na wypadek działań wojennych jest obowiązkiem każdego obywatela Rzeczypospolitej.

Ogromny skarbiec narodowy, świadczący o wielowiekowej kulturze Polski, o Jej wielkości i odrębności historycznej i kulturalnej został, w skutek kataklizmów dziejowych i ostatnich wojen, w dużej części zniszczony.

${ }^{51}$ F. Kopera, op. cit., s. 7.

52 Zob. Ustawa z 15 marca 1934 o obronie przeciwlotniczej i przeciwgazowej (Dz.U. 1934, nr 80, poz. 742); Rozporządzenie Rady Ministrów z 29 stycznia 1937 o przygotowaniu w czasie pokoju obrony przeciwlotniczej i przeciwgazowej Państwa (Dz.U. 1937, nr 10, poz. 73); Rozporządzenie Rady Ministrów z 24 stycznia 1939 o obowiązkach osób fizycznych i prawnych oraz władz i instytucyj w dziedzinie przygotowania personelu obrony przeciwlotniczej i przeciwgazowej w czasie pokoju (Dz.U. 1939, nr 10, poz. 54); Zarządzenie Ministra Spraw Wewnętrznych z 28 czerwca 1939 o organach obrony przeciwlotniczej i przeciwgazowej (M.P. 1939, nr 150, poz. 356). W latach trzydziestych znacznie nasiliła się również działalność edukacyjna instytucji państwowych zajmujaccych się obronnościa. Główne zadanie w tym zakresie należało do Ligi Obrony Powietrznej i Przeciwgazowej. Ukazujące się wydawnictwa miały na celu uświadomienie społeczeństwu zagrożeń związanych z wojną powietrzną i chociaż teoretyczne przygotowanie do nich. Zob. m.in.: S. Lewicki, Wobec grozy wojny powietrznej. Odczyt, Warszawa 1935; W.Z. Charlewski, Organizacja i zadania przeciwlotniczej stużby obserwacyjno-meldunkowej. Podręcznik dla personelu krajowych posterunków i central obserwacyjno-meldunkowych, Warszawa 1935; Z. Meliński, Zapobieganie pożarom w obronie przeciwlotniczej, Warszawa 1935; Z. Bartel, Zachowanie się ludności cywilnej przed napadem podczas napadu lotniczego i po napadzie: (krótki zarys), Warszawa 1936; Ogólna instrukcja o organizacji samoobrony ludności pod względem OPL, Poznań 1937; W. Krzyżanowski, Krótki podręcznik z zakresu obrony przeciwlotniczo-gazowej do użytku pracowników kolejowych członków poznańskiego okręu kolejowego L.O.P.P., Poznań 1938; Instrukcja Ministerstwa Opieki Społecznej W. 1/5-9 o organizacji ratownictwa sanitarnego $w$ samoobronie przeciwlotniczej i przeciwgazowej, Poznań 1939; Wskazówki dla komendantów opl domów (bloków domów), właścicieli domów oraz głównych lokatorów o urzqdzaniu pomieszczeń ochronnych dla celów samoobrony przeciwlotniczej, Warszawa 1939. 
Nie możemy dopuścić, aby pozostałe bogactwa z takim trudem chronione uległy pomniejszeniu.

Dlatego należy roztoczyć czujną i troskliwą opiekę nad wszelkiego rodzaju zabytkami, nieść pomoc przy ich zabezpieczaniu, czuwać nad obiektami porzuconymi przez właścicieli, zbierać wszystkie zabytki ruchome pozostawione bez opieki i składać w miejsca z góry ustalone i należycie zabezpieczone, utrzymywać jeśli to możliwe łączność z wojewódzkimi konserwatorami zabytków i pomagać im w zabezpieczaniu zabytków.

Każdy dokument, stara książka, obraz, rzeźba, ołtarz, nagrobek, kielich, monstrancja, ornat, szkło, porcelana, meble, gobeliny, tkaniny itp. o wartości artystycznej lub historycznej, zbiory archiwalne, biblioteczne i muzealne, wszelkiego rodzaju budynki zabytkowe, bez względu na właścicieli powinny znaleźć odpowiednią opiekę.

Należy pamiętać, że zniszczenie zabytku historycznego lub artystycznego stanowi niepowetowaną stratę dla kultury narodu ${ }^{53}$.

Pod koniec lipca 1939 rozpoczęto budowę schronów przeciwlotniczych, a w ostatnich dniach sierpnia kopanie rowów, w których w razie ataku lotniczego mogła się schronić nawet jedna czwarta mieszkańców Krakowa. Na łamach „Ilustrowanego Kuryera Codziennego” i „Czasu” zachęcano mieszkańców miasta do uczestnictwa w pracach, m.in. hasłem: „Wszyscy chwyćmy się łopaty, nic nie zrobią nam armaty!" Planowano również dokonanie taktycznych zniszczeń wokół miasta. Drukowano artykuły instruktarzowe dotyczące sztucznego oddychania, postępowania w przypadku zatrucia gazami bojowymi czy wykonania prowizorycznej maski gazowej ${ }^{54}$. Decyzja o wycofaniu się armii „Kraków” i odstapieniu od obrony w pierwszych dniach września spowodowała ogromną dezorganizację i wpłynęła bezpośrednio na akt poddania miasta ${ }^{55}$.

Równolegle do akcji podejmowanych przez władze miejskie, Muzeum prowadziło również wzmożone działania w zakresie ochrony posiadanych zbiorów $^{56}$. W dokumentach z kwietnia 1939, przygotowanych dla Wydziału

${ }^{53}$ AAN, MWRiOP, sygn. 7054, Notatka „Społeczny obowiązek ochrony zabytków” z września (?) 1939 , k. 347.

54 Zob. „Ilustrowany Kuryer Codzienny”, 27-31 VIII 1939, nr 236-240; „Czas”, 27-31 VIII 1939, nr 236-240.

${ }^{55}$ A. Bernaś-Kostynowicz, Społeczeństwo polskie w wojnie obronnej 1939. Wspótdziałanie ludności cywilnej $z$ wojskiem $w$ okresie zagrożenia i działań wojennych, Warszawa 1988, s. 130; Cz. Brzoza, Kraków polityczny, w: Kraków w latach 1918-1939, seria: „Dzieje Krakowa”, t. IV, red. J. Bieniarzówna, J.M. Małecki, Kraków 1997, s. 145-148; A.L. Sowa, Kraków i krakowskie we wrześniu 1939 roku w świetle historiografii, „Krzysztofory. Zeszyty Naukowe Muzeum Historycznego Miasta Krakowa” 1990, z. 17, s. 7-13. W 1939 ukazały się Tymczasowe wytyczne dla władz administracji ogólnej o ochronie obiektów, Warszawa 1939.

${ }^{56} \mathrm{O}$ działaniach związanych z zabezpieczeniem zbiorów w innych polskich instytucjach muzealnych zob. A. Szyszko-Bohusz, Wawel pod okupacja niemiecka. Wspomnienia $z$ lat 1939-1945, w: Kraków w latach okupacji 1939-1945. Studia i materiaty, Kraków 1949-1957, s. 155-156; R. Jarocki, Rozmowy z Lorentzem, Warszawa 1981, s. 164165; C. Skuza, op. cit., s. 30-35; L.H. Nicholas, op. cit., s. 59-64; Muzeum Czartoryskich. Historia i zbiory, Kraków 1998, s. 171-172; J. Pruszyński, op. cit., s. 407-409; D. Matelski, Losy polskiego dziedzictwa kulturalnego w latach drugiej wojny światowej 
Oświaty Zarządu Miasta Krakowa, Kopera informował o stanie przygotowań i zabezpieczeń poszczególnych budynków muzealnych.

W Sukiennicach wytypowano jedno z pomieszczeń od strony ul. św. Jana na półpiętrze na prowizoryczny schron dla personelu. Skrytki dla obiektów zaplanowane zostały w piwnicach od strony pomnika Adama Mickiewicza, zamykanych żelaznymi drzwiami, które „należałoby [...] lepiej uszczelnić”, a „wyloty wentylacyjne i przeznaczone dla zasypywania węgla, prowadzące z zewnątrz spod arkad do piwnic, mają być zabezpieczone płytami korkowymi i piaskiem”. Lokalizacja ta jednak miała zostać wykorzystana jedynie w sytuacji, gdyby nie udało się przewieźć obiektów do schronu w Nowym Gmachu. W celu zabezpieczenia przed rozprzestrzenieniem się pożaru zamontowano 6 hydrantów, które znajdowały się w salach: Średniowiecznej, Legionów, Wejściowej, Siemiradzkiego oraz bibliotece i pracowni naukowej. Podłączono dodatkowo sygnalizację alarmową mająca bezpośrednie połączenie ze strażą pożarna, umieszczając tzw. dzwonki w salach: Wyspiańskiego, Średniowiecznej, Racławickiej, Rusieckiego i w korytarzu prowadzącym do kancelarii oraz system automatycznego powiadamiania o pożarze. Zapasy piasku i wody zostały uzupełnione i złożone na jednym z tarasów. Kopera informował dalej, że w najbliższych dniach worki z piaskiem mają być umieszczone dodatkowo w salach ekspozycyjnych pod gablotami, a w większych ilościach „w westybulu za tryptykiem z Lusiny i pod postumentami w sali średniowiecznej”. Dodatkowo zgromadzono w Sukiennicach 6 masek gazowych, 2 latarki elektryczne, młotek, obcęgi, siekierę i liny oraz materiały do pakowania eksponatów. Na jednym z balkonów od ul. Brackiej zebrano wałki, na które miały zostać nawinięte obrazy dużych rozmiarów, a w piwnicy zgromadzono „21 pak tytoniowych, wypełnionych do połowy trocinami, które służyć będą do pakowania obiektów". Jako miejsca najbardziej zagrożone pożarem wskazywano niskie i łatwopalne strychy z niezwykle utrudnionym dostępem. Kopera pisał:

Strychy górne są szczególnie trudne do obrony. Dojście do nich z szatni z I p[iętra] schodami tak wąskimi, że tylko jedna szczupła osoba z trudnością może w górę się posuwać. [...] Ze względu na rozczłonkowanie górnych strychów oraz drewniane łatwopalne belkowanie potrzebna jest większa ilość przeciwpożarniczych posterunków obsługi ${ }^{57}$.

i po jej zakończeniu w historiografii, „Studia Podlaskie” 2007/2008, t. XVII, s. 302-305; J. Marecki, W trosce o archidiecezję. Wytyczne abpa Adama Stefana Sapiehy na wypadek wojny, w: Historia bliższa ludziom. Prace ofiarowane księdzu profesorowi Janowi Kracikowi $w$ 70. rocznicę urodzin, red. E.E. Wróbel, R. Szczurowski, Kraków 2011, s. 285-296; M. Kolmasiak, „Król żandarmów”. Biografia Walentego Wójcika przybocznego Marszatka Pitsudskiego, Radomsko 2013, s. 171-173; M. Matwijów, Mieczystaw Gębarowicz (18931984). Uczony i opiekun narodowych dóbr kultury, Warszawa 2013, s. 155; zob. też m.in.: AAN, MWRiOP, sygn. 7054, dokumenty związane z zabezpieczeniem arrasów wawelskich, k. $172-176$.

${ }^{57}$ AMNK, Kancelaria Kopery, dp. 122/39, „Galeria w Sukiennicach” z 22 IV 1939. 
Zwracał jednocześnie uwagę, że przeszklenie stropu uniemożliwi prowadzenie akcji zabezpieczania obiektów w nocy w sytuacji, gdy konieczne będzie zaciemnienie. Problem ten rozwiązano w ostatnich dniach sierpnia 1939 poprzez pokrycie świetlików czarną farba ${ }^{58}$.

Z uwagi na to, że wszystkie zbiory z Sukiennic miały zostać przewiezione do schronu w Nowym Gmachu, powołano trzy zespoły, których zadaniem było spakowanie i zabezpieczenie obiektów. W skład pierwszego zespołu wchodzili: Kwiatkowski jako kierownik oraz Zofia Exner, Marta Sumowska, Bronisława Kumaniecka, Stanisław Krupa, Kazimierz Rzeszutko, Andrzej Tomasik, Józef Jasikowski i Józef Machowski. Ich zadaniem było zapakowanie i zabezpieczenie eksponatów - obrazów, rzeźb, zabytków przemysłu artystycznego znajdujących się w salach: Średniowiecznej, Pamiątek i Rusieckiego. Drugi zespół miał za zadanie zabezpieczenie wszystkich obrazów znajdujących się na galerii, w tym czterech wielkich płócien - Hołdu pruskiego i Kościuszki pod Racławicami Matejki, Czwórki Józefa Chełmońskiego i Pochodni Nerona Henryka Siemiradzkiego oraz nawinięcie ich na wałki. W skład tej grupy weszli: Kazimierz Buczkowski jako kierownik oraz Anna Dutczyńska, Mieczysław Pogłódek, Jan Góralczyk, Pałaszyński, Jan Jurek i Piotr Bzdyl. Trzeci zespół, składający się z Wincentego Caby i Karola Golińskiego, miał zając się odbieraniem nadchodzacych transportów dzieł i ich bezpiecznym rozmieszczaniem w schronie w Nowym Gmachu ${ }^{59}$.

Jednopiętrowy budynek Muzeum Czapskich składał się z 12 sal ekspozycyjnych -4 na parterze i 8 na piętrze. Wejścia na strychy zabezpieczone były żelaznymi drzwiami. Kierownikiem obrony przeciwlotniczej została kustosz Maria Fredro-Boniecka wraz z przydzielonymi do pomocy Michałem Kompa, Bazylim Perczykiem, Bolesławem Stolarskim, Maria Nosek i Dorotą Gębarowską. Oddział wyposażono w piasek, 2 łopaty, 2 beczki z woda i 2 wiadra. Dla personelu przygotowano 2 maski gazowe, latarkę elektryczna, a dla zabezpieczenia i pakowania zbiorów - 2 drewniane skrzynie, 4 paki, 2 skrzynki tytoniowe, czarny papier i wióry do wypełniania skrzyń, obcęgi, młotek i siekierę. Najwartościowsze obiekty - pasy słuckie, złote i srebrne przedmioty, zegary, szkło, porcelanę oraz 50 najcenniejszych obrazów - miały zostać ukryte w schronie w Nowym Gmachu ${ }^{60}$.

Oddział im. Erazma Barącza mieścił się w jednopiętrowym domu na rogu ulic Karmelickiej 51 i Siemiradzkiego. Kamienicę od sąsiednich budynków łaźni miejskiej i koszar policji - oddzielały podwórza. Zabytki zgromadzono w salach ekspozycyjnych - 5 na parterze i 2 na pierwszym piętrze - najczęściej przy ścianach, rzadziej na środku pomieszczeń. Również i w przypadku tego

58 Ibidem; zob. ibidem, dp. 315/39, Pismo dotyczące usunięcia farby ze świetlików z 4 X 1939.

${ }^{59}$ Ibidem, dp. 122/39, „Galeria w Sukiennicach” z 22 IV 1939. Biogramy pracowników Muzeum zob. Rejestr pracowników..., passim.

${ }^{60}$ AMNK, Kancelaria Kopery, dp. 122/39, „Muzeum Czapskich, ul. Piłsudskiego 10-12” z 18 IV 1939. 
budynku elementami najbardziej narażonymi na zagrożenie pożarem były dwuspadowy, oparty na wiazaniach drewnianych, dach pokryty papa oraz drewniane stropy. Kopera oceniał stan kamienicy jako bardzo dobry. „Mury budynku sa grube - pisał - jako, że budynek jest przed kilkudziesięciu laty budowany, kiedy nie oszczędzano jeszcze na materiale", a jedyny zgłaszany przez niego postulat dotyczył podłączenia budynku do sieci telefonicznej. Oddział wyposażony był w 2 maski przeciwgazowe, 2 beczki na wodę i 2 wiadra, 2 fury piasku, 2 łopaty, siekierę, obcęgi i młotek oraz latarkę elektryczna. Plan ochrony zbiorów zakładał pozostawienie zabytków na miejscu, wyposażając budynek tylko w jedną zamykaną skrzynię dla ochrony najcenniejszych obiektów. Na osoby odpowiedzialne za bezpieczeństwo oddziału wyznaczeni zostali mieszkający tam kustosz zbiorów Władysław Prajer i woźny Stanisław Kotarba ${ }^{61}$.

Natomiast Oddział im. Feliksa Jasieńskiego, mieszczący się na rogu ul. Szczepańskiej 11 i pl. Szczepańskiego, zajmował jeden z najmniej problematycznych budynków. Muzealia przechowywane były w salach ekspozycyjnych - 9 na pierwszym i 6 na drugim piętrze oraz w bibliotece, pracowni, a nawet w szatni. Część najcenniejszych obiektów - obrazy zakupione z kościoła św. Katarzyny w Krakowie i inne malowidła średniowieczne oraz japońskie (Kakemona), drzeworyty japońskie i niektóre tkaniny - miała zostać spakowana do przygotowanych na ten cel 16 pak tytoniowych, 2 innych pak oraz 3 zamykanych skrzyń. Puste strychy posiadały drewniane belkowanie, ale przykryte były blacha. Pieczę nad budynkiem sprawował Edward Łepkowski wraz z Anną Mejro, Janem Tomczykiem i Józefem Rogala. Budynek przy ul. Szczepańskiej wyposażony został w 4 fury piasku, 2 łopaty, 2 dębowe beczki na wodę, 2 wiadra, siekierę, młotek i obcęgi, 2 maski gazowe oraz latarkę elektryczną z bateriami. Jedynym zgłaszanym zapotrzebowaniem było - podobnie jak w przypadku Oddziału im. Erazma Barącza - podłączenie budynku do sieci telefonicznej ${ }^{62}$.

W kolejnym oddziale - Muzeum Jana Matejki - zlokalizowanym w trzypiętrowej kamienicy przy ul. Floriańskiej 41, zabytki rozmieszczono na ścianach i w gablotach w salach ekspozycyjnych. Ponadto w holu znajdowały się szkice do polichromii. Na osobę odpowiedzialna za bezpieczeństwo obiektu wyznaczono kustosza zbiorów Szukiewicza, przydzielając mu do pomocy trzech woźnych: Walentego Chwałę, Feliksa Wolskiego i Tomasza Magdę. Zabezpieczenie przeciwpożarowe oddziału stanowiły 4 fury piasku, 2 beczki dębowe na wodę, 2 wiadra, 2 łopaty, 2 maski gazowe, latarka elektryczna, siekiera, młotek i obcęgi. Zbiory znajdujące się w oddziale miały zostać spakowane do przygotowanych skrzyń i umieszczone w piwnicy, a najcenniejsze z nich przewiezione do schronu w Nowym Gmachu ${ }^{63}$.

\footnotetext{
${ }^{61}$ Ibidem, „Oddział Muzeum Narodowego im. Erazma Barącza, ul. Karmelicka 51”, [b.d.].

${ }^{62}$ Ibidem, „Oddział im. Feliksa Jasieńskiego”, [b.d.].

${ }^{63}$ Ibidem, „Muzeum Jana Matejki, ul. Floriańska 41”, [b.d.].
} 
Dodatkowo w oddziałach wprowadzono instrukcję na wypadek alarmu lotniczego. Opisana w niej procedura dotyczyła zaciemnienia pomieszczeń, ustawienia posterunków przeciwpożarowych i ochrony, zaopatrzenia personelu w maski gazowe. Wymieniała również czynności na wypadek pożaru oraz te, które należało wykonać po zakończeniu bombardowania. Dla Sukiennic obowiązywała ponadto dodatkowa procedura postępowania dla zarządzonego pogotowia przeciwlotniczego ${ }^{64}$.

Pracownicy Muzeum wyposażeni zostali również w broń. Kopera miał rewolwer bębenkowy i 22 sztuki amunicji, natomiast brauningi z nabojami po 4 i 6 sztuk posiadali odpowiednio Kwiatkowski i Pogłódek ${ }^{65}$.

Wzmiankowany już kilkakrotnie wyżej schron w Nowym Gmachu Muzeum był przedmiotem starań zarówno Kopery, jak i dyrektora Biblioteki Jagiellońskiej Edwarda Kuntzego już od połowy 1938. Na rok przed wybuchem wojny żadna z krakowskich instytucji nie posiadała pomieszczenia zabezpieczonego przed atakami lotniczymi. Kuntze proponował, aby wykorzystując doświadczenia warszawskie, zaadaptować na schron jeden z fortów. Korespondencja pomiędzy dyrekcją Muzeum i Biblioteką Jagiellońską została przekazana do wiadomości Wydziału Oświaty i Zarządu Miasta Krakowa, jednak w odpowiedzi na jeden z listów Kuntzego, Kopera napisał:

[...] poruszoną sprawę schronu uważam również za bardzo ważną. W tej kwestii odniosłem się do Zarządu miasta, bez którego nie jestem w stanie nic pozytywnego i celowego przedsięwziąć. Sądzę, że Prezydium miasta zechce się nad tą ważną kwestią zastanowić i obmyśleć odpowiednie kroki z W[ielce] Sz[anownym] Panem i ze $m n a^{66}$.

Niemal rok później, w kwietniu 1939 schron w Nowym Gmachu nadal nie był gotowy. Kopera pisał: „konieczne jest wykończenie schronu, dyle na podłogę, gdyż inaczej wszystko od wilgoci się zniszczy, założenie światła elektrycznego, zamurowanie prowizorycznej ściany”67. Z pracami zdążono.

Dlatego na kilkanaście dni przed 2 września 1939 r. rozpoczęto pakowanie zbiorów dniami i nocami, przewożąc je do nowego gmachu przy Alei 3 Maja - do schronu. Beczki ze zbiorami numizmatycznymi zasmołowano i zakopano. Poza „Hołdem

${ }^{64}$ Ibidem, „Galeria w Sukiennicach”, [b.d.]; ibidem, „Oddział im. Feliksa Jasieńskiego”, [b.d.]; ibidem, „Muzeum Jana Matejki, ul. Floriańska 41”, [b.d.]; ibidem, „Muzeum Czapskich, ul. Piłsudskiego 10-12”, [b.d.]. Jednym ze środków biernej obrony przeciwlotniczej, mającej na celu ochronę ludności i obiektów przed nalotami, było utrudnianie wykonania tych nalotów przez maskowanie naturalne i sztuczne, zadymianie i zaciemnianie obiektów, budowanie atrap oraz oślepianie pilotów samolotu za pomocą reflektorów przeciwlotniczych. Ze względu na koszty na szeroką skalę stosowano jedynie zaciemnianie. Zob. A. Bernaś-Kostynowicz, op. cit., s. 74.

${ }^{65}$ AMNK, Kancelaria Kopery, dp. 286/39, Pismo do Zarządu Miejskiego w sprawie zwrotu broni z 7 IX 1939.

${ }^{66}$ Ibidem, dp. 198/38, Korespondencja Kuntzego i Kopery z 5 i 14 V 1938.

${ }^{67}$ Ibidem, dp. 122/39, „Galeria w Sukiennicach” z 22 IV 1939. 
Pruskim", który na żądanie Zarządu Miasta wywieziono do Zamościa - wszystkie zbiory Muzeum Narodowego zostały na miejscu w Krakowie ${ }^{68}$.

Zabezpieczanie zbiorów nie zakończyło się z chwilą wybuchu wojny ani nawet zajęcia Krakowa przez wojsko niemieckie. Od września 1939 chroniono zbiory głównie przed rabunkiem, za wszelką cenę starając się o pozyskanie rewersów na „wypożyczane” z Muzeum zabytkowe przedmioty. Dodatkowo, w związku z planowanym atakiem Niemców na Związek Sowiecki, odbyły się dwie konferencje poświęcone zabezpieczaniu zbiorów przed atakiem lotniczym i pożarem - 6 i 17 VI 1941. W sporządzonych z nich sprawozdaniach znalazły się informacje na temat stanu przeszkolenia pracowników Muzeum oraz zabezpieczeń technicznych w budynkach. Dokumenty te wykazały podstawowe braki w wyposażeniu - wśród dezyderatów były: pompa ręczna, sikawki i gaśnice, piasek oraz skrzynie do jego przechowywania, koce przeciwpożarowe określane jako płótno azbestowe, kilof, łopata, bosaki strażackie, liny. Proszono o odzież ochronna, w tym „garnitury”, w których skład wchodziły: kurtka, spodnie i pas strażacki, ubrania dla sanitariuszek - kitle, czepki, opaski na ramię oraz rękawice i obuwie. Wykazywano niedostateczna liczba latarek elektrycznych, gwizdków do alarmowania o zagrożeniu, pakietów opatrunkowych oraz czarnego papieru do zaciemnienia. Sprawdzenia wymagały hydranty, brakowało węży, które miały doprowadzić wodę do miejsc objętych pożarem. Dla osób pełniących straż proszono o trzy łóżka polowe. Na szczęście na Muzeum bomby nie spadły ${ }^{69}$.

Doświadczenia I wojny światowej miały ogromny wpływ na podjęte przez Koperę ćwierć wieku później działania i zdeterminowały przyjęte w 1939 metody postępowania. Istniejąca, przynajmniej w zarysie, ogólnopaństwowa strategia obronna oraz postawa innych instytucji opiekujacych się zbiorami nie wywołała działań skierowanych na ewakuację. Oczywiście, zarówno w 1914, jak i w 1939 było jasne, że wywiezienie zbiorów posiadanych przez Muzeum do bezpiecznych lokalizacji jest niewykonalne i ta forma zabezpieczania, z uwagi na liczbę obiektów, nie mogła być realnie brana pod uwagę. Widać natomiast stosowanie sprawdzonych już rozwiązań, np. w odniesieniu do numizmatów ukrycie w zasmołowanych i zakopanych beczkach czy przechowanie nawiniętych na rulony obrazów w zabezpieczonych gruzem piwnicach.

Należy stwierdzić, że przyjęte metody ochrony dla rzeczywistych zagrożeń dotyczących Muzeum w czasie II wojny światowej okazały się słuszne.

68 D. Błońska, O Muzeum Narodowym w Krakowie w czasie drugiej wojny światowej, „Klio” 2014, t. XXVIII, s. 107-108. Kwota przekazana Muzeum na ewakuację zbiorów we wrześniu wyniosła 734,95 zł. W grudniu 1939 upominano się o dodatkową kwotę 410,40 zł za sierpniowe transporty, zob. AMNK, Kancelaria Kopery, dp. 287/39 i 289/39, wyrachowanie z dotacji z 7 IX 1939; ibidem, dp. 408/39, zestawienie rachunków Miejskiego Zakładu Czyszczenia Miasta z 18 XII 1939.

${ }^{69}$ Ibidem, dp. 98/41, Pismo do Wydziału Oświaty i Kultury Zarządu Miasta z 9 VI 1941; ibidem, Protokół z konferencji w dniu 17 VI 1941. 
Zabezpieczenie zbiorów przed wybuchem wojny oraz dalsze prace prowadzone już podczas okupacji - np. zaklejenie lic obrazów czy ewidencjonowanie zabieranych przez Niemców zabytków - sprawdziły się w odniesieniu do zagrożenia rabunkiem. Nie ulega wątpliwości, że w głównej mierze przyczynił się do tego szczęśliwy dla Krakowa i tym samym dla Muzeum zbieg okoliczności powodujący, że miasto przez cały okres okupacji, jako stolica Generalnego Gubernatorstwa, nie było umyślnie niszczone. Szczęście dopisało również w 1945, oszczędzając Kraków przed wyzwoleniem przez Armię Czerwona. Niemniej jednak przedsięwzięte środki byłyby absolutnie niewystarczające w sytuacji militarnych działań wojennych, np. ataku bombowego.

Prowizoryczność podjętych działań i w dużym stopniu opieszałe ich prowadzenie stanowiło wynik nie tylko braku wiary w realność zagrożenia. Muzeum w 1938 i 1939 borykało się z problemami z ówczesnej perspektywy dużo ważniejszymi niż zagrożenie wojną. Były to przede wszystkim ciagłe braki lokalowe i wiążąca się z tym niemożliwość, ze względu na niedostatek finansów, zakończenia prac przy budowie Nowego Gmachu. Kopera, mający niemal 70 lat, chciał uwieńczyć swoje długoletnie zarządzanie instytucją oddaniem do użytku pięknego, specjalnie na cele muzealne wzniesionego obiektu i w tym kontekście nie można się dziwić, że odsuwał od siebie koszmar wojny i wywołanych nią zniszczeń.

Tak samo i polityka państwa polskiego, cieszącego się niepodległością niespełna 20 lat, wciąż nastawiona była przede wszystkim na budowę i rozbudowę, a nie na ochronę i zabezpieczanie. Wspominając sierpień 1939, Kopera i Buczkowski pisali:

[...] na kilka tygodni przed wybuchem wojny zaczęto się krzątać koło zabezpieczania zabytków miasta. Ze strony rządu, do ostatnich chwil wierzącego w możliwość pokojowego rozwiązania konfliktu, nie było w tym kierunku zdecydowanej akcji $\mathrm{z}$ wyjątkiem zabezpieczenia przeciwlotniczego. Akcja szła raczej od miasta, jego instytucji muzealnych, towarzystw mających na celu ochronę zabytków, wreszcie od osób prywatnych. Ochrona przeciwlotnicza, organizowana od dłuższego czasu, obejmowała budynki zabytkowe. Na gmachach Wawelu, Sukiennic, budynkach kościelnych pełniły służbę z poświęceniem pogotowia przeciwlotnicze. Lecz ani ich sprzęt, ani możliwości nie stały w jakimkolwiek stosunku do dynamiki wojny, która wzrastając w dalszym ciagu na sile, czyniła wszystkie przeciwlotnicze zabezpieczenia budynków zabytkowych bezcelowymi nawet na terenie państw najlepiej do wojny przygotowanych.

Zabytki ruchome pakowano i przenoszono do schronów. Zarządy muzeów dokonywały gigantycznego wysiłku celem zabezpieczenia dziesiątek tysięcy obiektów w ciagu bardzo krótkiego czasu. Pracowano dosłownie dniami i nocami. Ze względu jednak na brak specjalnych schronów przyszłość zabytków nie przedstawiała się różowo. O wywiezieniu programowym dzieł sztuki w głąb kraju lub za granicę nie było mowy choćby tylko z powodu braku środków transportowych. Panowała zreszta w tym względzie rozbieżność zdań... ${ }^{70}$

${ }^{70}$ F. Kopera, K. Buczkowski, Losy zabytków artystycznych Krakowa, w: Kraków pod rzadami wroga 1939-1945, red. J. Dąbrowski, Kraków 1946, s. 47-48. 


\section{Streszczenie}

Zabezpieczenie zbiorów Muzeum Narodowego w Krakowie na wypadek konfliktu zbrojnego nie było do tej pory przedmiotem naukowego opracowania. W niniejszym artykule autorka koncentruje się na ochronie zabytków podczas I i II wojny światowej. Krakowskie Muzeum Narodowe jest niezwykle ciekawym przykładem, gdyż w obydwu przypadkach odpowiedzialność spoczywała na tej samej osobie - długoletnim dyrektorze instytucji - Feliksie Koperze. Za pierwszym razem jego decyzje były efektem pomysłowości, a później umiejętności wyciagania wniosków z własnych doświadczeń. W obydwu sytuacjach wynikały z niezwykłej determinacji i odpowiedzialności za powierzoną mu bezcenną kolekcję oraz zbyt ogólnych i w żadnym razie niewystarczających wytycznych władz zwierzchnich w tym zakresie.

\section{Facing Disaster. Protection of the art collection of the National Museum in Krakow before the First and the Second World War}

Protection of the art collection of the National Museum in Krakow in case of armed conflict has not yet been the subject of scientific study. In this article, the author focuses on the protection of monuments during the First and the Second World War.

The National Museum in Krakow is an extremely interesting example, because in both cases responsibility rests with the same person - the longtime director of the institution, Feliks Kopera. At first, his decisions were the result of ingenuity and, later the ability to draw conclusions from personal experience. In both cases, it was the result of extraordinary determination and responsibility for priceless collections entrusted to him and the guidance provided to him be higher authorities that was insufficient and too general.

\section{Bibliografia}

Bartel Z., Zachowanie się ludności cywilnej przed napadem podczas napadu lotniczego i po napadzie, Warszawa 1936.

Bernaś-Kostynowicz A., Społeczeństwo polskie w wojnie obronnej 1939. Wspótdziatanie ludności cywilnej $w$ wojskiem $w$ okresie zagrożenia $i$ działań wojennych, Warszawa 1988.

Błońska D., Feliks Kopera (1871-1952). Menadżer kultury, naukowiec i dydaktyk. W 60. rocznice śmierci, „Rozprawy Muzeum Narodowego w Krakowie. Seria Nowa” 2012, t. V, s. 313-331.

Błońska D., O Muzeum Narodowym w Krakowie w czasie drugiej wojny światowej, „Klio” 2014, t. XXVIII, s. 85-128.

Brzoza Cz., Kraków polityczny, w: Kraków w latach 1918-1939, seria: „Dzieje Krakowa”, t. IV, red. J. Bieniarzówna, J.M. Małecki, Kraków 1997, s. 145-148.

Bujniewicz I., Ogólne zasady wycofania i rozmieszczenia mienia i ludzi na wypadek wojny $z$ Niemcami w okresie międzywojennym, „Przegląd Kwatermistrzowski” R. XIII, 1962, z. 2, s. 105-109.

Gumowski M., Wspomnienia numizmatyka, Kraków 1965.

„Hołd pruski” w Zamościu - wojenne dzieje obrazu. Ze wspomnień Eugeniusza Tora, oprac. do druku Z. Żygulski jun., „Rozprawy Muzeum Narodowego w Krakowie. Seria Nowa” 1999, t. I, s. 129-139.

Jarocki R., Rozmowy z Lorentzem, Warszawa 1981.

Kocójowa M., „Pamiatkom ojczystym ocalonym z burzy dziejowej”. Muzeum Emeryka Hutten-Czapskiego (Stańków-Kraków), Kraków 1978.

Kolmasiak M., „Król żandarmów”. Biografia Walentego Wójcika przybocznego marszatka Pitsudskiego, Radomsko 2013. 
Kopera F., Buczkowski K., Losy zabytków artystycznych Krakowa, w: Kraków pod rzadami wroga 1939-1945, red. J. Dąbrowski, Kraków 1946, s. 47-65.

Kopera F., Sprawozdanie Dyrekcyi Muzeum Narodowego w Krakowie za rok 1914/15, Kraków 1916.

Kopff A., Muzeum Narodowe w Krakowie. Historia i zbiory, Kraków 1962.

Krzyżanowski W., Krótki podręcznik z zakresu obrony przeciwlotniczo-gazowej do użytku pracowników kolejowych członków poznańskiego okręgu kolejowego L.O.P.P., Poznań 1938.

Lewicki S., Wobec grozy wojny powietrznej. Odczyt, Warszawa 1935.

Małecki M.J., W dobie autonomii galicyjskiej (1866-1918), w: Kraków w latach 1796-1918, seria: „Dzieje Krakowa”, t. III, red. J. Bieniarzówna, J.M. Małecki, Kraków 1979, s. 225-394.

Manikowska E., Wielka wojna i zabytki, w: Polskie dziedzictwo kulturowe u progu niepodległości wokót Towarzystwa Opieki nad Zabytkami Przeszłości, Warszawa 2010, s. 21-92.

Mansfeld B., Muzea na drodze do samoorganizacji. Zwiazek Muzeów w Polsce 1914-1951, Warszawa 2000.

Marecki J., W trosce o archidiecezję. Wytyczne abpa Adama Stefana Sapiehy na wypadek wojny, w: Historia bliższa ludziom. Prace ofiarowane księdzu profesorowi Janowi Kracikowi w 70. rocznicę urodzin, red. E.E. Wróbel, R. Szczurowski, Kraków 2011, s. 285-296.

Matelski D., Losy polskiego dziedzictwa kulturalnego w latach drugiej wojny światowej i po jej zakończeniu w historiografii, „Studia Podlaskie” 2007/2008, t. XVII, s. 299-318.

Matwijów M., Mieczystaw Gębarowicz (1893-1984). Uczony i opiekun narodowych dóbr kultury, Warszawa 2013.

Meliński Z., Zapobieganie pożarom w obronie przeciwlotniczej, Warszawa 1935.

„Monumentis Patriae...” Emerykowi Hutten-Czapskiemu w 110. rocznice śmierci Muzeum Narodowe w Krakowie, red. J. Skorupska, Kraków 2006.

Muzeum Czartoryskich. Historia i zbiory, Kraków 1998.

Nicholas L.H., Grabież Europy. Losy dziet sztuki w Trzeciej Rzeszy i podczas II wojny światowej, tłum. B. Sławomirska, Kraków 1997.

Nowak J.S., Marian Gumowski i jego spuścizna archiwalna w Muzeum Narodowym w Krakowie, „Rocznik Polskiego Towarzystwa Heraldycznego” 2013, seria nowa, t. XII (XXIII), s. $163-169$.

Pruszyński J., Dziedzictwo kultury Polski. Jego straty i ochrona prawna, t. I, Kraków 2001. Przygotowanie obronne państwa 1935-1939, cz. 1: Prawo i administracja, seria: „Wojskowe Teki Archiwalne", t. VI, Warszawa 2014.

Skorupska-Szarlej J., Rejestr pracowników Muzeum Narodowego w Krakowie, cz. 1: Do roku 1950, Kraków 2004.

Skuza C., Wojenne i powojenne losy skarbów narodowych, Toruń 1994.

Sowa A.L., Kraków i krakowskie we wrześniu 1939 roku w świetle historiografii, „Krzysztofory. Zeszyty Naukowe Muzeum Historycznego Miasta Krakowa” 1990, z. 17, s. 7-13.

Staniszewski W., O tych co uratowali „Hotd pruski”, http://www.robertkusmierz.com/zamosc/ zamosc.php?d=wydarzenia\&a=hold_pruski (dostęp: 19 IV 2016).

Szyszko-Bohusz A., Wawel pod okupacja niemiecka. Wspomnienia z lat 1939-1945, w: Kraków w latach okupacji 1939-1945. Studia i materiaty, Kraków 1949-1957, s. 155-156.

Bi o g r a m: Diana Błońska - mgr, kustosz w Muzeum Narodowym w Krakowie, kierownik Archiwum MNK, doktorantka w Instytucie Historii Uniwersytetu Jagiellońskiego, współpracownik Polskiego Słownika Biograficznego. Jest autorką artykułów poświęconych historii Muzeum Narodowego w Krakowie i dziejom muzealnictwa pierwszej połowy XX wieku. E-mail:dblonska@mnk.pl. 